\title{
The Oldest Species of Dolichotis (Rodentia, Hystricognathi) from the Pliocene of Argentina: Redescription and Taxonomic Status of "Orthomyctera" chapalmalense
}

\author{
María Carolina Madozzo-Jaén ${ }^{1,2}$ (D) $\cdot$ María Encarnación Pérez ${ }^{1}$ (D) Cecilia Marcela Deschamps $^{3}$ (D)
}

Accepted: 21 June 2021 / Published online: 19 August 2021

(c) The Author(s), under exclusive licence to Springer Science+Business Media, LLC, part of Springer Nature 2021

\begin{abstract}
The Subfamily Dolichotinae comprises two living species, Dolichotis patagonum, an emblematic component of the Patagonian fauna of Argentina, and Dolichotis salinicola, endemic to the Chaco ecoregion. These two species are also considered as pertaining to different genera, D. patagonum and Pediolagus salinicola. The oldest records of Dolichotis come from the Pliocene-Pleistocene boundary of northeastern and central Argentina, and the late Pleistocene from southern Brazil, and northern and southern Uruguay. Five fossil species were described from the Pleistocene and Holocene in central Argentina (D. minor, D. plathycephala, D. major, D. intermedia, and D. improla). "Orthomyctera" chapalmalense was described on the basis of remains from the coast of Mar del Plata and Chapadmalal, Buenos Aires Province, Chapadmalal Formation (late Pliocene, 3.74-3.04 Ma). A new detailed description of the holotype and its comparison with closely related taxa suggests that this species is more related to the genus Dolichotis, resulting in the new combination $D$. chapalmalense. The close affinities with Dolichotis revealed by phylogenetic analyses combined with molecular and morphological characters were corroborated in previous analyses. The origin of this lineage extends at least to a million years ago, taking the record back to the middle Pliocene. The evolutionary novelties that appear at least since the Pliocene, marking a key period for the Caviidae, are analyzed. Based on a phylogenetic perspective with the inclusion of the fossil record, our data support the inclusion of the two species (D. patagonum and D. salinicola) in a single genus.
\end{abstract}

Keywords Caviidae $\cdot$ Dolichotinae $\cdot$ Morphology $\cdot$ Phylogeny $\cdot$ Chapadmalalan $\cdot$ Evolution

The living Dolichotinae are represented by only two species and, although there is consensus that both species represent well-differentiated taxa, their taxonomic assignment at the

María Carolina Madozzo-Jaén

cmadozzojaen@mef.org.ar

María Encarnación Pérez

mperez@mef.org.ar

Cecilia Marcela Deschamps

ceci@fcnym.unlp.edu.ar

1 Consejo Nacional de Investigaciones Científicas y Técnicas (CONICET), Museo Paleontológico Egidio Feruglio (MEF), Av. Fontana 140, U9100 Trelew, Chubut, Argentina

2 Facultad de Ciencias Naturales e Instituto Miguel Lillo, Universidad Nacional de Tucumán (UNT), Miguel Lillo 205, T4000 San Miguel de Tucumán, Tucumán, Argentina

3 División Paleontología Vertebrados, Museo de La Plata (UNLP), Paseo del Bosque s/n, B1900FWA La Plata, Argentina generic level is controversial. Some authors consider a single genus: Dolichotis with the species D. patagonum and $D$. salinicola (e.g., Woods and Kilpatrick 2005; Pérez and Pol 2012; Dunnum 2015; Madozzo-Jaén 2019; this work), while others assign different genera to each species: Dolichotis patagonum and Pediolagus salinicola (e.g., Marelli 1927; Mares and Ojeda 1982; Rowe and Honeycutt 2002; Álvarez et al. 2013, 2015; Campo et al. 2020).

The type species of Dolichotis, D. patagonum or mara, is an emblematic component of the Patagonian fauna of Argentina (Fig. 1). It includes two subspecies recognized by the pelage color; one of them has a more southern distribution (Cabrera 1953; Campos et al. 2001; Dunnum 2015), from the provinces of Buenos Aires and southern Córdoba to Santa Cruz, and the other, further north, inhabiting south of Catamarca, east of La Rioja, northwest of Córdoba, and southwest of Santiago del Estero (Cabrera 1953; Campos et al. 2001; Dunnum 2015; Alonso Roldán et al. 2019). The small species, D. salinicola or conejo de los palos is 


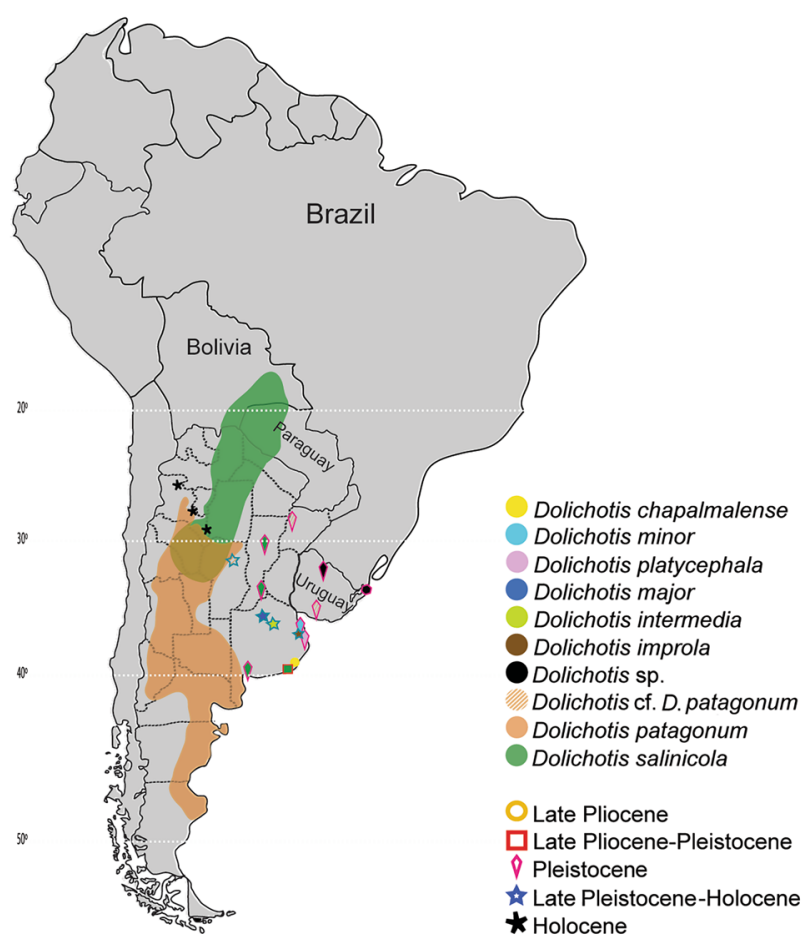

Fig. 1 Distribution of Dolichotis species. Dolichotis chapalmalense, yellow; Dolichotis minor, light blue; Dolichotis platycephala, light pink; Dolichotis major, blue; Dolichotis intermedia, light green; Dolichotis improla brown; Dolichotis sp. black; Dolichotis $\mathrm{cf}$. D. patagonum, striped orange; Dolichotis patagonum, orange; Dolichotis salinicola, green. Late Pliocene, orange circle; late Pliocene-Pleistocene, red square; Pleistocene, diamond fuchsia; late Pleistocene-Holocene blue star; Holocene, black asterisk; current shading Dolichotis patagonum, orange; Dolichotis salinicola green

endemic to the Chaco ecoregion, typical of arid forests; it is distributed in the arid and semi-arid lands of southern Bolivia, and Paraguay, and in Argentina in the provinces of Formosa, Tucumán, Santiago del Estero, Salta, Catamarca, Chaco, La Rioja, and Córdoba. The distribution of both species overlaps in central Argentina (Fig. 1; Cabrera 1953; Mares and Ojeda 1982; Campos et al. 2001; Dunnum 2015; Alonso Roldán et al. 2019; Mora and Ojeda 2019). Recently, according to their conservation status, the mara is classified as vulnerable and the conejo de los palos as least concern. The loss of native habitat by the advance of the farming frontier, as well as illegal hunting are the main threats to both species (Carreño et al. 2009; Caldas et al. 2015; Alonso Roldán et al. 2019; Mora and Ojeda 2019).

The diversity of Dolichotinae in the fossil record is much higher than the present one and the oldest records date to the late Miocene from northwestern Argentina (MadozzoJaén 2019). Several Miocene-Holocene species have been assigned to this subfamily and grouped in five genera: Dolichotis, Orthomyctera, Prodolichotis, Propediolagus, and Pliodolichotis. However, the last two correspond to Microcavia and Dolicavia (Quintana 1996, 1997: Propediolagus), and Procardiomys (pers. obs. MEP: Pliodolichotis), respectively. Moreover, Orthomyctera and Prodolichotis have been used indistinctly and including different nominal species. Recently, Madozzo-Jaén (2019) corroborated the validity of the type species of Prodolichotis and in consequence, of the genus. Finally, the type species of Orthomyctera, $O$. rigens, is included in the subfamily Caviinae (in revision MCM-J and MEP; see Results section here). The first records of Dolichotis were found in the late Pliocene (Biozone of Platygonus scagliai, Cione et al. 2015) and in the late Pleistocene of Buenos Aires Province, Argentina (Cione and Tonni 1999, 2001, 2005). Dolichotis patagonum was also reported for the Pleistocene of Corrientes Province (Fig. 1; Álvarez 1974; Herbst and Álvarez 1977; Francia et al. 2019) and the late Pleistocene-Holocene of Córdoba Province, Argentina (Dolichotis cf D. patagonum, Martínez Sarrat 2009). Remains of this species were also recorded in the late Pleistocene of southeastern Brazil (Kerber et al. 2011) and northern and southern Uruguay (Ubilla et al. 2004, 2009). The oldest record of D. salinicola comes from the Pliocene-Pleistocene boundary of Punta San Andrés (Verzi and Quintana 2005), the late Pleistocene of the east of Buenos Aires Province (Tonni 1981), as well as from central and southern Santa Fe Province, Argentina (Vezzosi 2015). Remains of both current species were found in the Holocene of archaeological contexts of Catamarca (e.g., Rodriguez Larredo 1998; Lema et al. 2009; del Papa et al. 2010). Other extinct species of Dolichotis were recorded in central Argentina. Two of them were described for the Pleistocene (Dolichotis minor and D. plathycephala) and three species for the Pleistocene-Holocene boundary (Fig. 1; Dolichotis major, D. intermedia and D. improla; Gervais and Ameghino 1880; Ameghino 1889, 1891; Kraglievich 1932). The species of the late Miocene-Pliocene were originally described within Dolichotis but some of them were formally transferred to other genera (e.g., Prodolichotis prisca; Prodolichotis mendocina), and others are under revision (e.g., "Orthomyctera" andina, Rovereto 1914; Kraglievich 1932; Madozzo-Jaén 2019; Madozzo-Jaén and Pérez in revision).

"Orthomyctera" chapalmalense in Ameghino (1908) comes from the coastal cliffs of Mar del Plata and Chapadmalal, Buenos Aires Province, in sediments assigned to the Chapadmalal Formation (late Pliocene, 4 to 3.3; Schultz et al. 1998; Beilinson et al. 2017; 3.74 to 3.04 Ma; Prevosti et al. 2021). Subsequently Kraglievich (1930a) suggested that it does not belong to this genus, and other authors recommended to include "Orthomyctera" chapalmalense in the genus Dolichotis because of the differences with the type species of the genus Orthomyctera (Orthomyctera rigens, Ubilla and Rinderknecht 2003; Madozzo-Jaén 2019). In addition, the available phylogenetic analyses corroborated the close affinities between "O." chapalmalense and Dolichotis (e.g., Pérez 2010; Pérez and Pol 2012), but until now, 
the taxonomic status of "Orthomyctera" chapalmalense has not been formally discussed.

The aim of this work is to analyze the taxonomic status of "Orthomyctera" chapalmalense, through a detailed description of the holotype (the only known specimen) and comparison with closely related taxa. In addition, the supra specific rank of the current species of Dolichotinae is discussed based on a comprehensive phylogenetic framework.
Institutional Abbreviations CML Colección Mamíferos Lillo, San Miguel de Tucumán, Tucumán, Argentina; MACNA Museo Argentino de Ciencias Naturales "Bernardino Rivadavia," Colección Ameghino, Ciudad Autónoma de Buenos Aires, Buenos Aires, Argentina; MLP Museo de La Plata, La Plata, Buenos Aires, Argentina; MNHNP-PAM Museum National de Histoire Naturelle, Pampeano Collection, Paris. France.

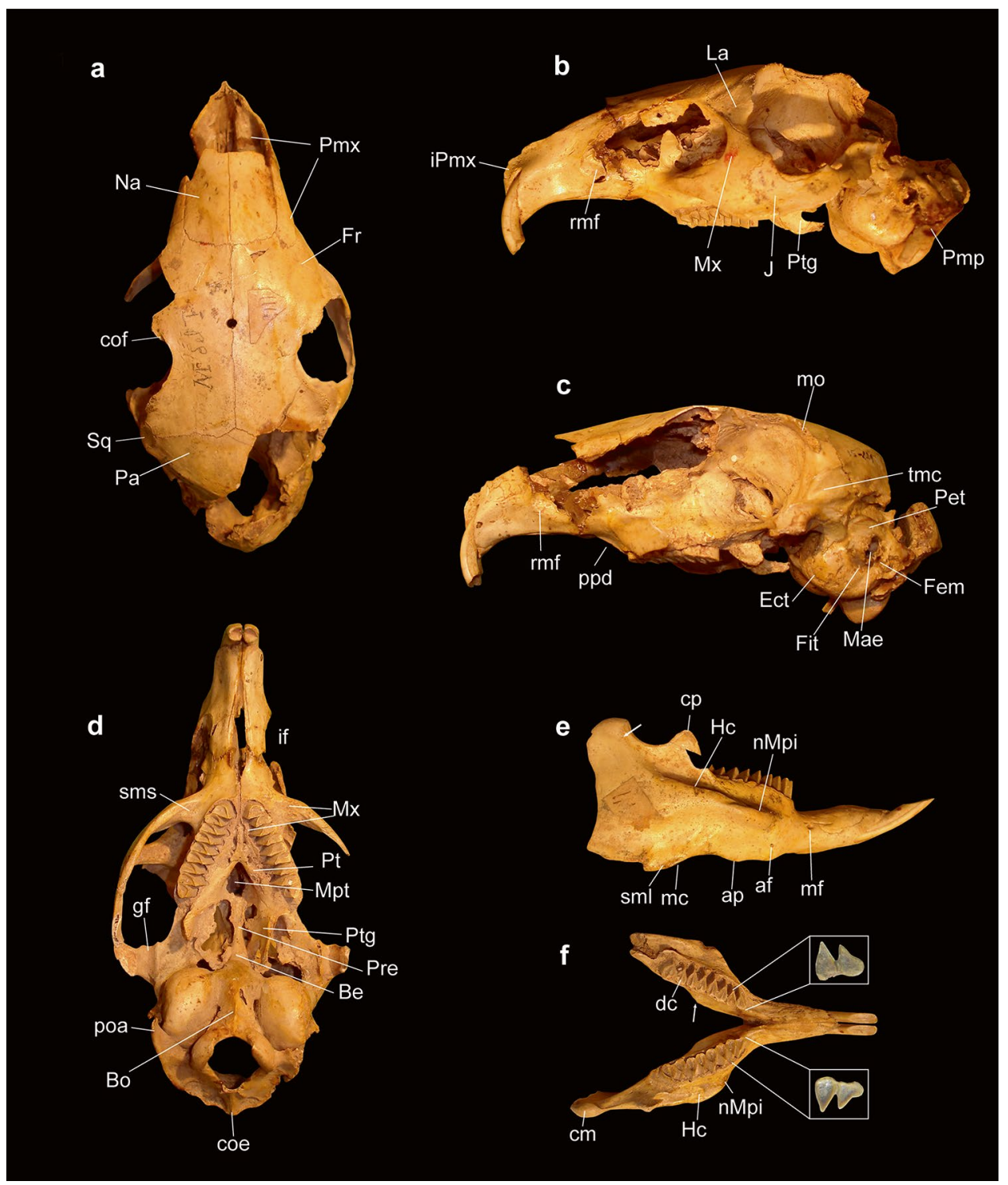

Fig. 2 Dolichotis chapalmalense MPL15-229 (holotype). a cranium in dorsal view; b-c cranium in lateral view; $\mathbf{d}$ cranium in ventral view; e dentary in lateral view; $\mathbf{f}$ occlusal view of molariform series and a detail of p4. Cranial abbreviations: Be basisphenoid; Bo basioccipital; cof canal frontal branch of ophthalmic nerve and superior ophthalmic artery; Ect ectotympanic; Fem stylomastoid foramen; Fit infratympanic fenestra; Fr frontal; gf glenoid fossa; if incisive foramen; iPmx incisive process of the premaxilla; J Jugal; La lacrimal; Mae external auditory meatus; mo orbital margin; Mpt mesopterygoid fossa; Mx maxilla; Na nasal; Pa Parietal; Pet epitympanic sinus;
Pmp mastoid process of the petrosal; Pmx premaxilla; poa paraoccipital apophysis; ppd posterior portion of diastema; Pre presphenoid; Pt palatine; Ptg pterygoid; rmf rostral masseteric fossa; sms scar of insertion of the masseter superficialis muscle; Sq squamosal; tmc temporal canal for the passage of the temporal muscle. Mandibular abbreviations: af accessory foramen; ap alveolar protuberances; cm mandibular condyle; cp coronoid process; dc dentine crest; Hc horizontal crest; mc masseteric crest; mf mental foramen; nMpi masseter medialis pars infraorbitalis muscle; sml scar for the masseter lateralis pars anterior 
Anatomical Abbreviations Hf/hf hypoflexus/id; HPE external primary flexus; hpi primary internal flex; HSE external secondary flexus; M1/m1 upper/lower first molar; M2/ m2 upper/lower second molar; M3/m3 upper/lower third molar; nMpi notch of masseter medialis pars infraorbitalis muscle; P4/p4 upper/lower fourth premolar.

Anatomical Nomenclature The cranial nomenclature follows Wahlert (1974), Wible et al. (2005), and Cherem and Ferigolo (2012); the mandibular nomenclature follows Woods and Howland (1979) and Pérez (2010); and the dental nomenclature follows Mones (1991) and Pérez (2010).

Phylogenetic Analysis The affinities of "Orthomyctera" chapalmalense within Caviidae were tested in successive cladistics analyses (e.g., Pérez 2010; Pérez and Pol 2012). In this paper we use datasets combined from Candela et al. (2021) and Madozzo-Jaén (2019). The combined matrix (Supplementary Online Material 1) for this analysis resulted in 77 taxa (six taxa have been added), 164 morphological characters (one cranial characters, eight tegumentary characters and one postcranial characters have been added), and 4014 mitochondrial and nuclear DNA sequences taken from GenBank (see Supplementary Online Material 2). The phylogenetic analysis was conducted using TNT 1.1 (Goloboff and Catalano 2016), the search was performed with the implemented tree fusing and sectorial searches (new technology searches), and it was set to stop after reaching the minimum length 1000 times. The branch length to measure the amount of changes within Cavioidea was quantified using TNT (Goloboff and Catalano 2016).

Principal Coordinates Analysis (PCoA) A principal coordinate analysis (PCoA) was performed to assess the similarity of "Orthomyctera" chapalmalense, D. patagonum, and $D$. salinicola in the context of Cavioidea within a lowdimensional space, based on the 164 morphological characters used to perform the cladistic analysis (Supplementary Online Material 1, 4), in which cranial, mandibular, dental, postcranial, and tegumentary characters of extant and fossil cavioids were scored (see Phylogenetic Analysis). Some fossil cavioids (i.e., stem group of Cavioidea sensu stricto, see Pérez 2010) were removed from the character matrix prior to any subsequent analyses. The PCoA was performed using PAST (Hammer et al. 2001), which has the ability to handle an incomplete matrix. Similarity was computed with the Gower Similarity index that is a well-known and widely used measure of proximity of mixed data types. Data not applicable were treated as missing. The Eigenvalue scaling option was selected, each axis using the square root of the Eigenvalue.

\section{Material and Methods}

The holotype of "Orthomyctera" chapalmalense (MPL 15-229; Fig. 2a-f) is the only specimen known and consists of a cranium and associated mandible with complete dental series. Although the cranium is currently broken, some fragments are preserved (i.e., anterior portion of rostrum, maxilla with complete row of teeth, anterior portion of frontal, tympanic bullae) and the description was supported with pictures previously taken (MEP).

The description of "Orthomyctera" chapalmalense is compared with the living species of Dolichotis (D. patagonum and $D$. salinicola) and the holotypes of the fossil species assigned to this genus (D. improla [MACN-A 2176], D. platycephala, [MACN-A 556], and D. intermedia [MACNA 1256]). The holotypes of D. minor (MNHNP-PAM 265: Kerodon minor) and D. major (MNHNP-PAM 267: Kerodon major) were not studied because we could not access the collection of the museum in Paris. However, we have analyzed the specimen MACN-A 1482 assigned to $D$. major by Ameghino (1889). Furthermore, we compared "O." chapalmalense with the type species of Orthomyctera $(O$. rigens MACN-A 1661) and Prodolichotis (P. prisca MACN 8348).

Measurements were taken with a $0.01 \mathrm{~mm}$ resolution digital caliper (Tables 1-4).

All relevant data are included in this article and supplement.

\section{Systematic Paleontology}

RoDENTIA Bowdich, 1821

HySTRICOGNATHI Tullberg, 1899

CAVIoIDEA (Fischer de Waldheim, 1817) sensu Kraglievich, 1930b

CAVIIDAE (Fischer de Waldheim, 1817) sensu Waterhouse, 1839

Dolichotinae Pocock, 1922

Dolichotis chapalmalense (Ameghino, 1908), nov. comb. Figure 2; Tables 1-4

1908. Orthomyctera chapalmalense Ameghino, p. 425.

Holotype MLP 15-229, cranium and mandible with complete dental series.

Geographic and Stratigraphic Occurrence Chapadmalal, Buenos Aires Province, Chapadmalal Formation; South American Land Mammal Age (SALMA; Ameghino 1908; Cione and Tonni 2005). 
Table 1 Compared measurements (in $\mathrm{mm}$ ) of the crania of Dolichotis chapalmalense, Dolichotis platycephala, Dolichotis patagonum, Dolichotis salinicola, Orthomyctera rigens, and Prodolichotis prisca. Abbreviations LT anteroposterior length of the cranium in dorsal view; $\mathrm{LN}$ anteroposterior length of the nasal; WN posterior width of the nasal between the nasal-frontal-premaxilla suture; OC orbital constric- tion; LF anteroposterior length of the frontal; WB width of the braincase; D upper diastema; IF anteroposterior length of the incisive foramen; P anteroposterior length of the palate; WP4 width of the palate at the level of P4; WM3 width of the palate at level of the M3; LB maximum length of bullae; LJ anteroposterior length of the jugal; SMJ dorsoventral length of the maxillary-jugal suture

\begin{tabular}{|c|c|c|c|c|c|c|}
\hline & $\begin{array}{l}\text { Dolichotis } \\
\text { chapalmalense }\end{array}$ & Dolichotis platycephala & $\begin{array}{l}\text { Dolichotis } \\
\text { patagonum }\end{array}$ & $\begin{array}{l}\text { Dolichotis } \\
\text { salinicola }\end{array}$ & Prodolichotis prisca & Orthomyctera rigens \\
\hline & MLP 15-229 & MANC-A 556 & average & & MACN 8348 & MACN-A 1661 \\
\hline LT & 123.94 & 114.89 & 118.93 & 88.41 & $82.75^{*}$ & - \\
\hline $\mathrm{LN}$ & - & 41.84 & 43.26 & 29.27 & 21.12 & - \\
\hline WN & 23.63 & 23.55 & 21.61 & 13.43 & 13.54 & - \\
\hline $\mathrm{OC}$ & 32.40 & 45.36 & 43.81 & 28.02 & - & - \\
\hline $\mathrm{LF}$ & 45.72 & 50.81 & 48.73 & 36.75 & - & - \\
\hline WB & 48.12 & 54.31 & 48.52 & 35.00 & 28.49 & - \\
\hline $\mathrm{D}$ & 42.02 & 42.49 & 44.30 & 26.30 & 22.84 & - \\
\hline IF & 28.75 & 22.68 & 20.38 & 15.48 & 13.78 & 8.95 \\
\hline $\mathrm{P}$ & 12.09 & 15.24 & 13.49 & 8.39 & 9,20 & 13.26 \\
\hline WP4 & 15.03 & 15.93 & 15.65 & 10.49 & 10.15 & 10.51 \\
\hline WM3 & 31.80 & 31.86 & 30.62 & 19.96 & 18.47 & - \\
\hline LB & 19.31 & - & 26.99 & 16.59 & 22.61 & - \\
\hline $\mathrm{LJ}$ & - & 33.08 & 34.95 & 22.87 & - & - \\
\hline SMJ & 15.81 & 23.02 & 18.66 & 9.71 & - & - \\
\hline
\end{tabular}

Emended Diagnosis Dolichotis chapalmalense differs from the other species of Dolichotis by having: cheek teeth anteroposteriorly longer than D. patagonum, D. salinicola, D. platycephala, D. major, D. improla, and D. intermedia; lower incisors extended up to the posterior lobe of $\mathrm{m} 2$, differing from $D$. intermedia and $D$. major; anterior projection of 44 developed, differing from $D$. intermedia and some specimens of $D$. patagonum. Length between the posterior border of the incisive foramen and alveolus of $\mathrm{P} 4$ shorter than in D. patagonum and D. salinicola; narrower interorbital width at the level of the posterior half of the dorsolateral border of the frontal, differing from D. patagonum, D. salinicola, and D. platycephala; mesopterygoid fossa with acuminate anterior border and straight divergent margins, differing from D. patagonum; anteroposterior length of dentary shorter than D. patagonum and D. major and longer than $D$. intermedia and $D$. salinicola. Maximum curvature of curve between postcondyloid process and angular process (or lunar notch) is located at the midpoint in the dorsoventral length of dentary, differing from $D$. patagonum and $D$. salinicola. Horizontal crest extended up to the anterior margin of the mandibular condyle, differing from $D$. patagonum, $D$. major, and $D$. intermedia; coronoid process projected dorsally, contrasting with $D$. patagonum and $D$. salinicola; hystricognathous fossa developed and extended up to midpoint of the condyle, differing from $D$. intermedia and D. major.

\section{Description}

\section{Cranium}

The dimensions of the cranium (Fig. 2a-d) are similar to those of D. patagonum (Fig. 3a-h) and D. platycephala, and larger than D. salinicola (Table 1; Figs. 4a-i, 6a). However, the rostrum is more robust than that of D. patagonum and $D$. salinicola and subtly less than that of D. platycephala; proportionally, the orbital constriction (OC) is more marked than in the other species and the relationship between the maximum mediolateral length of the braincase (WB) and the total length (LT) is similar to D. patagonum and $D$. salinicola and smaller than D. platycephala (Table 1; Fig. 6a).

Nasal The nasals are broken, preserving only the posterior portions, which are similar to those of $D$. patagonum (Figs. 2a, 3a). The lateral and medial margins are straight 


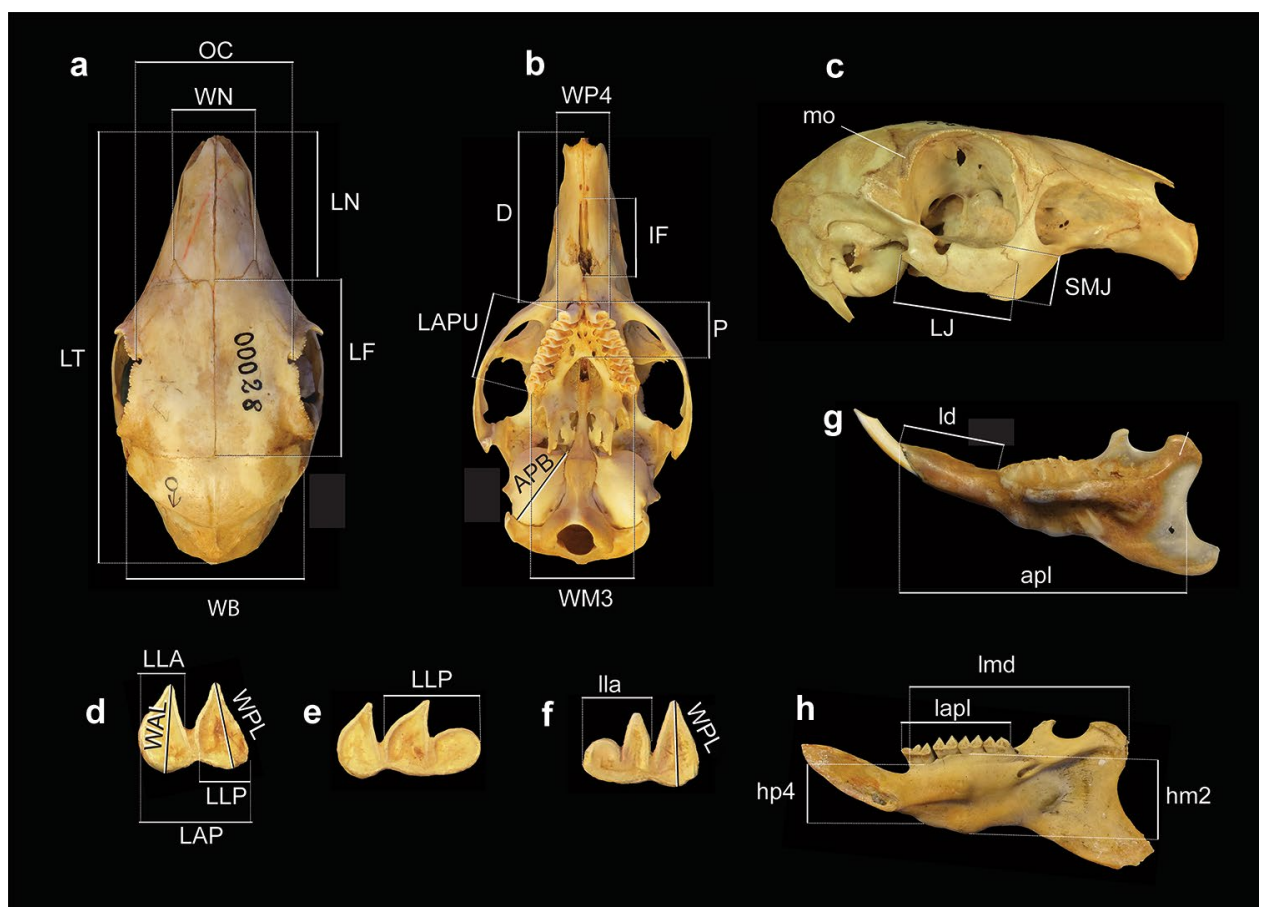

Fig. 3 Measurements used in the comparative analysis. Dolichotis patagonum cranim CML 5066; mandible CML 481. a skull in dorsal view; b cranium in ventral view; c cranium in lateral view; $\mathbf{d}$ upper second molar (M2); e upper third molar (M3); f lower first premolar (p4); $\mathbf{g}$ dentary in lateral view; $\mathbf{h}$ dentary in lingual view. Cranial abbreviations: APB maximum length of bullae; $\mathbf{D}$ diastema; IF anteroposterior length of the incisive foramen; LAPU length of upper dental series; $\mathbf{L F}$ anteroposterior length of the frontal; $\mathbf{L J}$ anteroposterior length of the jugal; $\mathbf{L N}$ anteroposterior length of the nasal; $\mathbf{L T}$ anteroposterior length of the cranium in dorsal view; OC orbital constriction; $\mathbf{P}$ anteroposterior length of the palate; $\mathbf{S M J}$ dorsoventral length of the maxillary-jugal suture; WB width of the braincase; WM3

and the posterior border is slightly anteriorly concave as in D. patagonum, D. salinicola, and D. platycephala (Fig. 4a). The nasal-frontal suture in other species of Dolichotis is variable, from anteriorly concave up to irregular.

Premaxilla In dorsal view, the dorsal process of the premaxilla is extended posteriorly beyond the nasal (Fig. 2a) as in D. patagonum and D. salinicola (Fig. 4a-b). In lateral view, the incisive process of the premaxilla (Fig. $2 b-c)$ is similar to $D$. patagonum and $D$. salinicola. In ventral view (Fig. 2d), the incisive foramen is elongated with pointed ends as in D. patagonum, D. salinicola, and D. platycephala (Figs. 3b, 4e-f); the premaxilla extends to the posterior third of the diastema.

Maxilla In lateral view (Fig. 2b-c), the posterior portion of the diastema (i.e., maxilla between the posterior border of the incisive foramen and the anterior margin of the alveolus of P4) is obliquely oriented and its anteroposterior length resembles that of $D$. patagonum and is shorter than in $D$. width of the palate at the level of M3; WN posterior width of the nasal at the level of the maxilla-frontal-premaxilla suture; WP4 width of the palate at the level of P4. Mandibular abbreviations: apl, anteroposterior length of the dentary; hm2 dentary height at $\mathrm{m} 2$ level; hp4 dentary height at $\mathrm{p} 4$ level; lapl length of lower dental series; Id anteroposterior length of the diastema; Imd anteroposterior length from the alveolus of $\mathrm{p} 4$ to the mandibular condyle. Dental abbreviations: LAP/lap anteroposterior length of upper/lower molariforms; LLA/lla anteroposterior length of anterior lobe of molariforms; LLP/llp anteroposterior length of posterior lobe of molariforms; WAL/wal mediolateral length of the anterior lobe of molariforms; WPL/wpl mediolateral length of the posterior lobe of molariforms

salinicola. The anterior margin of the orbit (dorsal zygomatic process of the maxilla) is dorsoventrally oriented and continuous throughout its length, similar to D. salinicola and $D$. platycephala and differing from $D$. patagonum in which this character is variable (Fig. $4 \mathrm{a}-\mathrm{c}$ ). In some specimens the dorsal zygomatic process is continuous throughout its length (Fig. 3c), in others it is interrupted by the position and extension of the lacrimal bone (e.g., CML 9789).

In ventral view (Fig. 2d), the diastema is longer than the dental series. The origin of the ventral root of the zygomatic process is at the level of $\mathrm{P} 4$; the scar of the origin of the masseter superficialis muscle is shallower than in D. patagonum. The medial portion of the maxilla, in the palate, is flat and triangular (as in D. patagonum, D. salinicola, and D. platycephala; Fig. $4 \mathrm{~g}-\mathrm{h}$ ), with a narrow medial crest, and a lateral palatal foramen at the level of P4-M1 (Fig. 2d).

Lacrimal The lacrimal in lateral view (Fig. 2b) is triangular; anteriorly and ventrally it contacts with the maxilla, 
Fig. 4 Skull of Dolichotis species. a-c dorsal view; $\mathbf{d}-\mathbf{f}$ lateral view; $\mathbf{g}-\mathbf{i}$ ventral view; $\mathbf{a}, \mathbf{d}, \mathbf{g}$ Dolichotis salinicola MLP 672; b, e, $\mathbf{h}$ Dolichotis patagonum b, h CML 481, e CML 9789; c, f, i Dolichotis platycephala MACN-A 556. Scale $=10 \mathrm{~mm}$. Abbreviations as in Figs. 2, 3

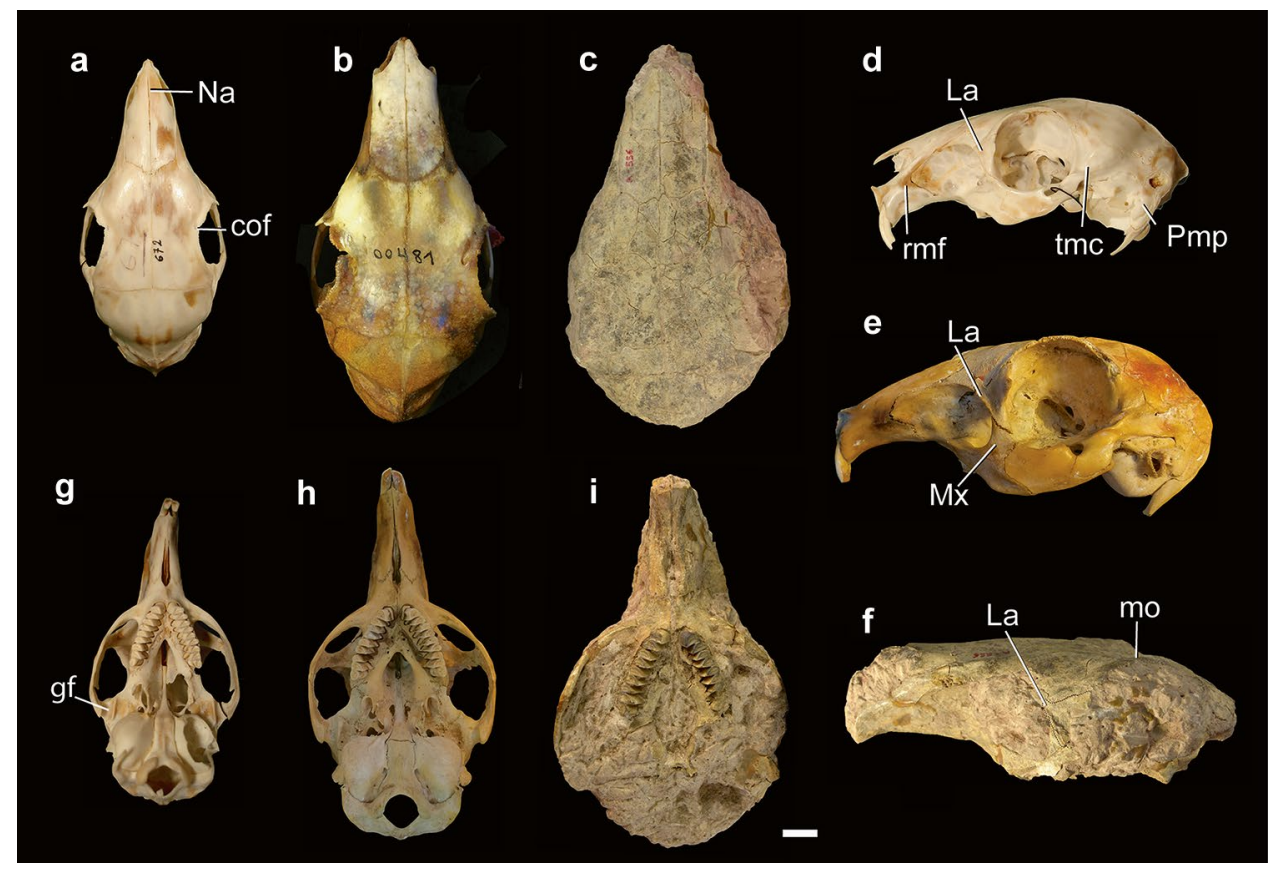

and dorsomedially with the frontal, as in D. salinicola and D. platycephala (Fig. 4b, d). It differs from D. patagonum, because the lacrimal is interposed in the anterior margin of the orbit (zygomatic process of the maxilla; Fig. 4d; Kraglievich 1930a) and ventrally contacts the jugal. The lacrimal foramen opens posteriorly in the orbital region as in D. patagonum and D. salinicola.

Palatine In ventral view (Fig. 2d), the contact of the palatine with the maxilla runs anteromedially-posterolaterally, with the anterior point at the level of M1. The anterior border of the mesopterygoid fossa is at the level of the anterior lobe of M2, and acuminate, with divergent margins giving the palatine a triangular shape; this condition resembles that of $D$. salinicola and D. platycephala, whereas D. patagonum has more vaulted divergent margins (Figs. 3b, 4e-f). The proportion between the length of the palate and the length of cranium is similar to that of D. salinicola, D. patagonum, and $D$. platycephala (Fig. 6a). The palatal vacuity is convex ventrally and the anteroventral margin of the alar canal is posteriorly concave.

Frontal In dorsal view (Fig. 2a), the frontal is dorsally plane along its entire extension; the nasal process of the frontal (sensu Cherem and Ferigolo 2012) is a small anterolateral projection between the premaxilla and the nasal. In the dorsal margin of the orbit, the passage for the frontal branch of the ophthalmic nerve and the superior ophthalmic artery (Wahlert 1974) forms a canal (Fig. 2a), differing from D. patagonum and D. salinicola (Figs. 3a, 4a), in which it forms a foramen that can be closed or laterally open. In some individuals of $D$. patagonum, the left notch is open and the right one is closed. In lateral view (Fig. 2c), the orbital margin is partially broken, but the preserved portion forms a lateral ledge with a subtle laterodorsal inclination as in $D$. patagonum, D. platycephala, and D. salinicola (Fig. 4d-f).

Parietal The preserved parietal (Fig. 2a) consists in a left fragment that contacts the frontal and squamosal. The anterior portion is slightly convex and the preserved portion of the temporal fossa is similar to that of D. patagonum and $D$. salinicola (Figs. 3a, 4a-b). In lateral view (Fig. 2c), a fragment of the lateral ledge of the orbital margin seems to be continuous with the squamosal, but it is broken and cannot be compared with the other species.

Jugal The jugal occupies $44 \%$ of the length of the ventral root of the zygomatic arch, the dorsal margin is partially broken and the ventral margin is straight (Table 1; Fig. 2bc). In other species of Dolichotis (e.g., D. patagonum), the dorsal margin has a dorsal process that varies from low with rounded edges to having spines posteriorly projected. The maxilla-jugal suture is posteriorly concave; its dorsoventral length is proportionally shorter than in D. patagonum and D. platycephala and longer than in D. salinicola (Table 1).

Squamosal The squamosal preserves mainly the zygomatic portion and the posterolateral portion of the orbit wall (Fig. 2b-c). In lateral view, the temporal canal for the passage of the temporal muscle is as in D. platycephala, dorsoventrally more extended than in $D$. patagonum and $D$. salinicola (Figs. 2c, 4d-e). The frontal-squamosal suture 
Table 2 Compared measurements (in $\mathrm{mm}$ ) of the mandibles of Dolichotis chapalmalense, D. patagonum, D. salinicola, D. major, and D. intermedia. Abbreviations apl anteroposterior length of the dentary; hm2 dentary height at $\mathrm{m} 2$ level; hp4 dentary height at $\mathrm{p} 4$ level; ld anteroposterior length of the diastema; lmd anteroposterior length from the alveolus of $\mathrm{p} 4$ to the mandibular condyle

\begin{tabular}{|c|c|c|c|c|c|}
\hline & $\begin{array}{l}\text { Dolichotis } \\
\text { chapalmalense }\end{array}$ & $\begin{array}{l}\text { Dolichotis } \\
\text { patagonum }\end{array}$ & $\begin{array}{l}\text { Dolichotis } \\
\text { salinicola }\end{array}$ & Dolichotis major & Dolichotis intermedia \\
\hline & MLP 15-229 & \multicolumn{2}{|c|}{ average } & MACN-A 1482 & MACN-A 1256 \\
\hline apl & 71.72 & 82.31 & 48.24 & 75.34 & \\
\hline $\operatorname{lmd}$ & 53.39 & 59.61 & 35.07 & 56.22 & 50.53 \\
\hline ld & 22.65 & 29.84 & 15.02 & 27.13 & 20.56 \\
\hline hp4 & 16.32 & 20.34 & 9.91 & 19.71 & 16.14 \\
\hline $\mathrm{hm} 2$ & 19.94 & 24.15 & 11.73 & 21.98 & 17.64 \\
\hline
\end{tabular}

is more posterior than in D. patagonum and D. salinicola, and the dorsal portion of the contact between the parietal and squamosal is dorsoventrally oriented, differing from $D$. patagonum and D. salinicola, in which it is slightly anteriorly concave and more anteroposteriorly oriented. In this way, the anterodorsal portion of the squamosal acquires a sigmoidal-shape (Figs. 2c, 3c). In ventral view (Fig. 2d), the glenoid fossa has a small projection in the anterior margin as in D. patagonum, but different from $D$. salinicola in which this projection is absent (Fig. $4 \mathrm{~g}-\mathrm{h}$ ).

Tympanic Bulla The tympanic bulla is proportionally smaller than in D. patagonum and D. salinicola. In lateral view (Fig. 2b-c), the epitympanic portion of the petrosal or epitympanic sinus is bullet-shaped and the external auditory meatus is at the level of the dental series as in other Dolichotinae (Fig. 3c). The stylomastoid foramen is smaller than the infratympanic fenestra. The mastoid portion of the petrosal is laterally exposed, dorsoventrally oriented and plane as in D. patagonum and D. salinicola (Figs. $2 \mathrm{~b}, 4 \mathrm{~d}-\mathrm{e}$ ). In ventral view, the major axis of the tympanic bulla is anteromedialposterolaterally oriented.
Presphenoid and Basisphenoid These bones are fused indicating an adult individual stage; part of the contact between the presphenoid and the palatine in the internal wall of the cranial cavity is broken. The basisphenoid is elongated, anteriorly narrow and wider at the posterior end (Fig. 2d), as in D. patagonum and D. salinicola (Fig. $4 \mathrm{~g}-\mathrm{h}$ ). The contact with the basioccipital is covered by resin which prevents its description. A well-developed crest on the posterior portion differentiates the basioccipital from that of D. patagonum and D. salinicola, in which it is absent.

Occipital Complex The supraoccipital (Fig. 2a) is dorsally exposed as in D. patagonum and D. salinicola. In posterior view, the external occipital crests are wide, and the dorsal nuchal crest is developed (Fig. 2d) as in D. patagonum and D. salinicola. The occipital condyles that border the foramen magnum are convex in the lateral and medial portions. In ventral view, these are anteromedial-posterolaterally oriented and, in posterior view, they are dorsoventrally elongated. The hypoglossal foramen is dorsal to the occipital condyles. The ventral portion of the right paraoccipital apophysis (the only one preserved) is broken and extends
Fig. 5 Dentary of Dolichotis a-c lateral view; $\mathbf{d - f}$ lingual view; $\mathbf{g}-\mathbf{i}$ occlusal view of molariform series; $\mathbf{a}, \mathbf{d}, \mathbf{g}$ Dolichotis salinicola MLP 672; b, e, h Dolichotis major MACN-A 1482; c, f, i Dolichotis intermedia MACN-A 1256. Scale $=10 \mathrm{~mm}$. Abbreviations: hgf hystricognathous fossa; ptgc pterygoid crest and as in Figs. 2, 3

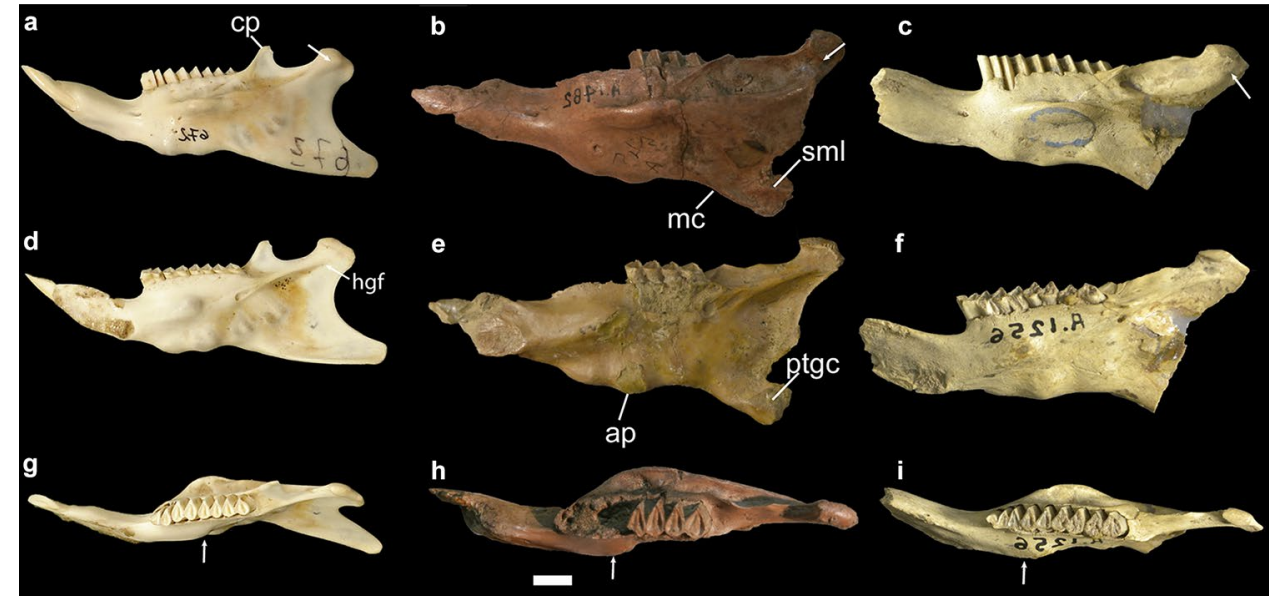


a

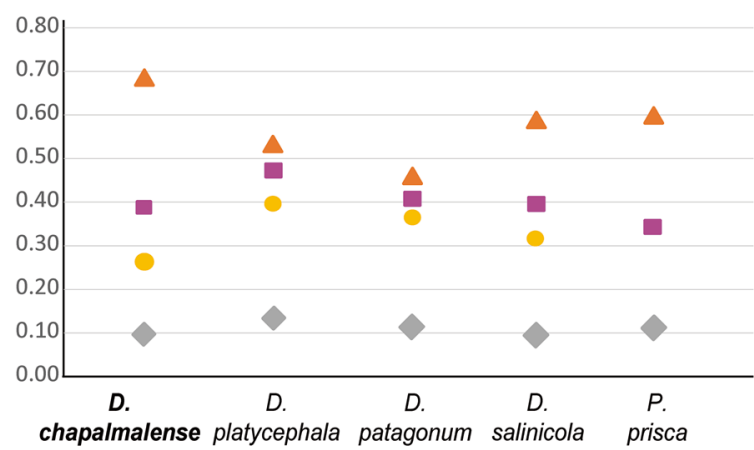

- OC/LT $\diamond \mathrm{P} / \mathrm{LT}$

-WB/LT $\triangle$ IF/D $\underset{\text { lap p4 } 4}{\text { LAP P4 }} \stackrel{\text { LAP m1 } 1}{\text { lap } 1}$

$D$.

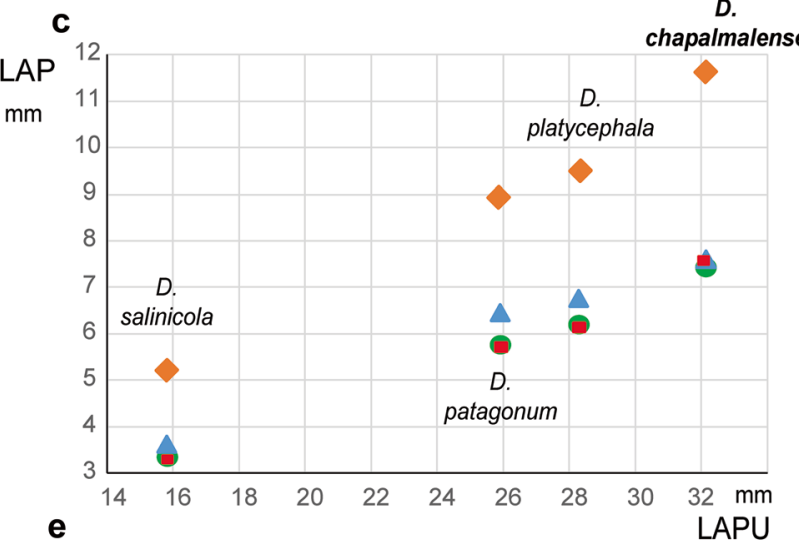

LAP/WT

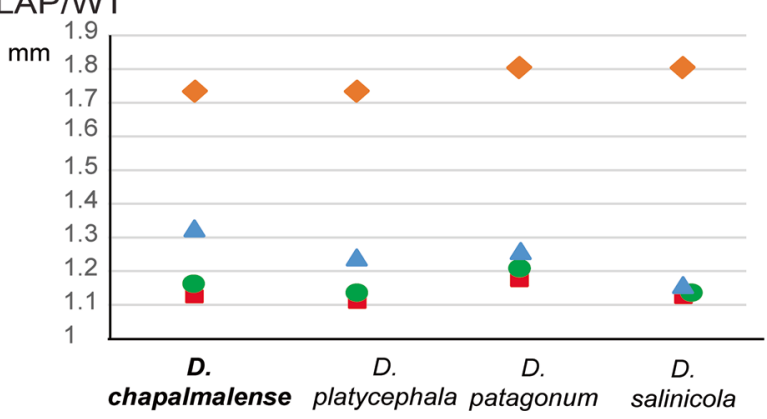

Fig. 6 Plot of measurements of Dolichotis. a Cranial measurements: relationship of orbital constriction width (OC) with respect to the anteroposterior length of the cranium (LT, yellow circle), width of the braincase (WB)/LT (violet square), length of palate $(\mathbf{P}) / \mathbf{L T}$ (grey rhombus), incisive foramen (IF)/diastema (D, orange triangle); b Mandibular measurements: relationship of the dorsoventral length at p4 level (hp4) with respect to the anteroposterior length of the dentary (lmd, pink rhombus), dorsoventral length at m2 level (hm2)/lmd (turquoise square), anteroposterior length of diastema (ld)/lmd (green rectangle); c Bivariant plot of anteroposterior length of upper

ventrally to the ventral border of the occipital condyle, as in D. patagonum and D. salinicola (Figs. $2 \mathrm{~d}, 4 \mathrm{~g}-\mathrm{h}$ ). In ventral view (Fig. 2d), the basioccipital is rectangular, anteroposteriorly elongated with a low ridge in the back half. b

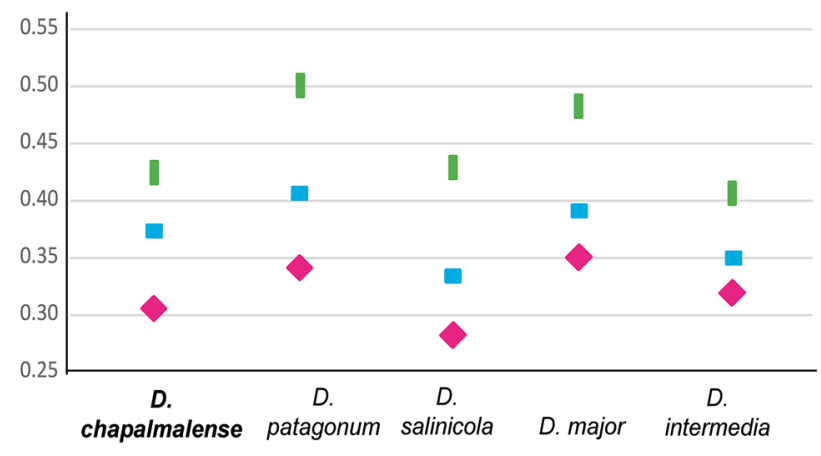
- LAP m2 LAP m3 $\quad \stackrel{\mathrm{hp} 4 / \mathrm{lmd}}{\mathrm{hm} 2 / \mathrm{md}}$

Id/lmd

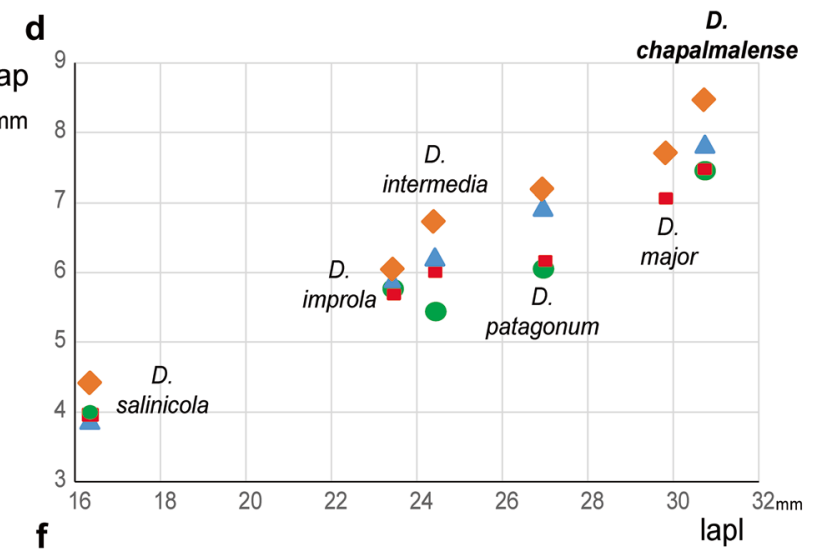

lap/wt

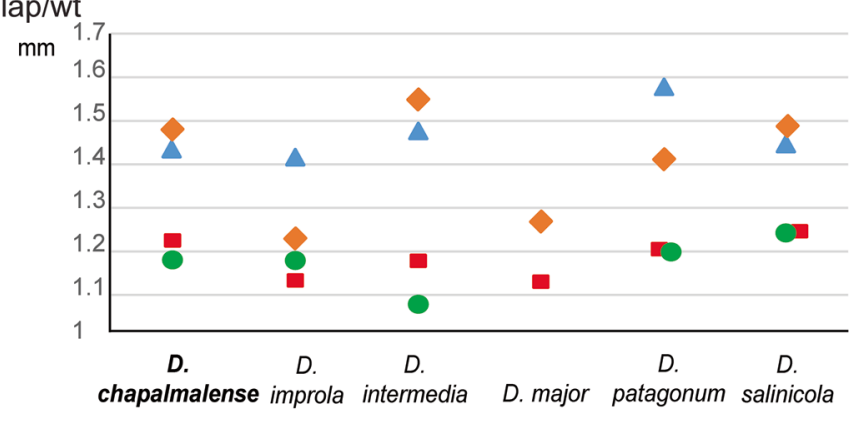

molariforms (P4-M3 LAP) and anteroposterior length of upper dental series (LAPU); d Bivariant plot of anteroposterior length of lower molariforms (p4-m3 lap) and anteroposterior length of lower dental series (lapl); e Plot of the relationship of anteroposterior length of upper molariforms (P4-M3 LAP) with respect to the average of mediolateral length of upper molars (P4-M3 WT); f Relationship of the anteroposterior length of lower molariforms (p4-m3 lap) with respect to the average of mediolateral length of lower molars ( $\mathrm{p} 4-\mathrm{m} 3 \mathbf{w t}$ ). LAP P4/lap p4 blue triangle; LAP M1/lap m1, green circle; LAP M2/ lap $\mathrm{m} 2$, red square; LAP M3/lap m3, orange rhombus

Dentary The dentary is smaller than that of $D$. patagonum and $D$. major and larger than D. intermedia and D. salinicola (Table 2; Fig. 5). The anteroposterior length of the diastema is shorter than the molariforms series, differing 
from $D$. patagonum in which the relationship is reversed (Tables 2, 3). In lateral view (Fig. 2e), the mental foramen is anterior to $\mathrm{p} 4$, at half the dorsoventral height of the lateral surface of the dentary. An accessory foramen is located ventral to the notch of the masseter medialis pars infraorbitalis muscle (nMpi), near the ventral margin as in D. patagonum, $D$. salinicola, $D$. intermedia, and $D$. major. The $\mathrm{nMpi}$ is between $\mathrm{m} 1-\mathrm{m} 2$ as in $D$. patagonum, D. salinicola, $D$. intermedia, and $D$. major, and connects posteriorly with the horizontal crest. This crest forms a well-developed shelf posteriorly extending up to the anterior margin of the mandibular condyle (Fig. 2e). The posterior extension resembles the condition present in some specimens of $D$. salinicola (Fig. 5a) and differs from $D$. patagonum, in which it reaches the anteroposterior midpoint of the mandibular condyle, and from $D$. intermedia and $D$. major in which it reaches the posterior border of the mandibular condyle (Figs. 3g, 5b-c). The lateral crest is straight as in D. intermedia, D. major, $D$. patagonum, and D. salinicola. The coronoid process is dorsally projected and differs from $D$. patagonum and $D$. salinicola in which it is posteriorly projected (Figs. 2e, 3g, $5 a)$. The mandibular condyle is rounded, with the labial edge not projected laterally respect to the wall of the dentary. The most anterior point of the lunar notch is at the midpoint of the dorsoventral length and differs from D. patagonum and $D$. salinicola in that the anterior point is located above the dorsoventral midpoint of the dentary. The dorsal fossa for the insertion of the masseter medialis muscle is deeper than the nMpi. The masseteric crest is soft and the masseter lateralis pars anterior muscle forms a scar as in D. patagonum, $D$. salinicola, and $D$. intermedia, but is different from $D$. major in which the masseteric crest and the scar are more defined (Figs. 2e, 5b). On the ventral margin of the dentary, the alveolar protuberances are well developed as in the other Dolichotinae. In lingual view (Fig. 2f), the incisor is posteriorly extended to the level of the anterior lobe of $\mathrm{m} 2$ as in D. patagonum, D. salinicola, D. intermedia, and D. major (Fig. $5 \mathrm{~g}-\mathrm{i}$ ). The mylohyoid crest is absent as in other species of Dolichotis and the pterygoid crest is less marked than $D$. major. The hystricognathous fossa extends up to the anterior portion of the mandibular condyle as in D. patagonum and $D$. salinicola and differs from $D$. intermedia, and D. major, in which the fossa extends to the posterior portion of the mandibular condyle (Fig. 5d-f).

\section{Cheek teeth}

The dental series are anteriorly convergent as in the other caviids (Fig. 2e-f). The cheek teeth are euhypsodont, bilobulate, double heart-shaped with a constriction in the apex of the lobes and with a transverse dentine crest in the middle of the occlusal surface of each lobe, as in other Dolichotinae (Fig. 2d, f). The hypoflexus/id (Hf/hf) is funnel-shaped with cement as in the other dolichotines; a furrow opposite to the hypoflexus/id is present in the labial/lingual border of the upper/lower molariforms respectively (Fig. 2d, f) as in other Dolichotinae (e.g., Prodolichotis prisca, D. patagonum, D. platycephala). The enamel is interrupted on the labial side of the molariforms, except in the flexus/id opposite to the hypoflexus/id as in other Dolichotinae.

The cheek teeth of $D$. chapalmalense are larger than those of D. patagonum as reported by Ameghino (1908) in the original description (Table 4; Fig. 6c-f). The lobes of M1/ $\mathrm{m} 1$ and M2/m2 are symmetrical as in other Dolichotis. The upper dental series is longer than in D. platycephala and $D$. salinicola and the lower one is similar to D. major and longer than $D$. salinicola, $D$. improla, and $D$. intermedia (Table 4; Fig. 6c-f). The P4 is anteroposteriorly longer than $\mathrm{M} 1, \mathrm{M} 1$ is similar in size to M2, and M3 is longer than the other molariforms (Table 3; Fig. 6d). The posterior projection of M3 is developed as an incipient third lobe with cement in the flexus formed with the posterior lobe as in $D$. patagonum, D. salinicola, and D. platycephala (Figs. 3b, $4 \mathrm{~g}-\mathrm{h})$. The $\mathrm{p} 4$ is anteroposteriorly longer than $\mathrm{m} 1$ and $\mathrm{m} 2$, and $\mathrm{m} 3$ is longer than the other molariforms, as in other species of Dolichotis (Table 4). The p4 has an anterior projection that is more developed on the right $\mathrm{p} 4$ than on the left p4. It is similar to D. salinicola (Fig. 5g), D. improla, and some specimens of D. patagonum (e.g., CML 481; CML 5066), but differs from other specimens of D. patagonum (e.g., CML 1380; CML 9789) and D. intermedia, in which the anterior projection is like an incipient lobe (Figs. 3f, 5i).

\section{Differences with Orthomyctera and Prodolichotis}

In order to explore the morphological differences among $D$. chapalmalense, Orthomyctera, and Prodolichotis, they were compared with the holotypes of the type species.

Orthomyctera rigens (MACN-A 1661) was found in the locality of Farola Monte Hermoso, Buenos Aires Province (early Pliocene, Zanclean). The main differences are related to size, and cranial and dental morphology. Size: D. chapalmalense is approximately $50 \%$ longer than $O$. rigens. Molarifoms: $O$. rigens has a small flexus in the posterior lobe of molariforms (HSE) and the projection of M3 is posteriorly oriented. Skull: In ventral view, the incisive foramina of $O$. rigens are triangular in shape.

Prodolichotis prisca (MACN 8348, Rovereto 1914) comes from the late Miocene - early Pliocene from northwestern Argentina (Tucumán and Catamarca provinces). This species was recently validated in morphological and phylogenetic analyses by Madozzo-Jaén (2019). Size: D. 
Table 3 Compared measurements (in $\mathrm{mm}$ ) of the upper molariforms of Dolichotis chapalmalense, Dolichotis platycephala, Dolichotis patagonum, Dolichotis salinicola. Abbreviations L, left; LAP, anteroposterior length of molariforms; LLA, anteroposterior length of anterior lobe of molariforms;

LLP, anteroposterior length of posterior lobe of molariforms; R, right; WAL, mediolateral length of anterior lobe of molariforms; WPL, mediolateral length of posterior lobe of molariforms

\begin{tabular}{|c|c|c|c|c|c|}
\hline & & $\begin{array}{l}\text { Dolichotis } \\
\text { chapalmalense }\end{array}$ & Dolichotis platycephala & $\begin{array}{l}\text { Dolichotis } \\
\text { patagonum }\end{array}$ & $\begin{array}{l}\text { Dolichotis } \\
\text { salinicola }\end{array}$ \\
\hline & & MLP 15-229 & MACN-A 556 & & \\
\hline \multirow[t]{2}{*}{ LAP dental series } & $\mathrm{R}$ & 32.25 & 28.37 & 26.20 & 15.13 \\
\hline & $\mathrm{L}$ & 32.02 & 28.25 & 25.66 & 16.55 \\
\hline \multirow[t]{2}{*}{ LAP P4 } & $\mathrm{R}$ & 7.71 & 6.61 & 6.56 & 3.59 \\
\hline & $\mathrm{L}$ & 7.50 & 6.92 & 6.38 & 3.64 \\
\hline \multirow[t]{2}{*}{ LLA } & $\mathrm{R}$ & 3.52 & 2.81 & 3.12 & 1.78 \\
\hline & $\mathrm{L}$ & 2.70 & 3.31 & 2.99 & 1.75 \\
\hline \multirow[t]{2}{*}{ LLP } & $\mathrm{R}$ & 3.99 & 3.19 & 3.12 & 1.67 \\
\hline & $\mathrm{L}$ & 2.21 & 2.97 & 3.12 & 1.74 \\
\hline \multirow[t]{2}{*}{ WAL } & $\mathrm{R}$ & 5.52 & 4.84 & 5.00 & 2.79 \\
\hline & $\mathrm{L}$ & 4.72 & 5.58 & 5.02 & 3.19 \\
\hline \multirow[t]{2}{*}{ WPL } & $\mathrm{R}$ & 6.23 & 5.54 & 5.27 & 3.02 \\
\hline & $\mathrm{L}$ & 6.47 & 5.85 & 5.23 & 3.46 \\
\hline \multirow[t]{2}{*}{ LAP M1 } & $\mathrm{R}$ & 7.02 & 6.02 & 5.78 & 3.21 \\
\hline & $\mathrm{L}$ & 7.55 & 6.37 & 5.72 & 3.47 \\
\hline \multirow{2}{*}{ LLA } & $\mathrm{R}$ & 3.00 & 2.44 & 2.55 & 1.53 \\
\hline & $\mathrm{L}$ & 2.42 & 2.60 & 2.51 & 1.59 \\
\hline \multirow[t]{2}{*}{ LLP } & $\mathrm{R}$ & 3.62 & 3.15 & 3.10 & 1.68 \\
\hline & $\mathrm{L}$ & 2.80 & 3.25 & 3.00 & 1.71 \\
\hline \multirow[t]{2}{*}{ WAL } & $\mathrm{R}$ & 5.91 & 5.11 & 4.74 & 2.99 \\
\hline & $\mathrm{L}$ & 4.84 & 5.67 & 4.68 & 2.99 \\
\hline \multirow[t]{2}{*}{ WPL } & $\mathrm{R}$ & 5.83 & 5.46 & 4.83 & 2.93 \\
\hline & $\mathrm{L}$ & 4.69 & 5.58 & 4.77 & 2.95 \\
\hline \multirow[t]{2}{*}{ LAP M2 } & $\mathrm{R}$ & 7.47 & 6.06 & 5.73 & 3.22 \\
\hline & $\mathrm{L}$ & 7.68 & 6.22 & 5.70 & 3.37 \\
\hline \multirow[t]{2}{*}{ LLA } & $\mathrm{R}$ & 3.28 & 2.50 & 2.48 & 1.52 \\
\hline & $\mathrm{L}$ & 2.55 & 2.76 & 2.53 & 1.49 \\
\hline \multirow[t]{2}{*}{ LLP } & $\mathrm{R}$ & 3.81 & 3.28 & 2.99 & 1.56 \\
\hline & $\mathrm{L}$ & 2.89 & 3.18 & 2.93 & 1.63 \\
\hline \multirow[t]{2}{*}{ WAL } & $\mathrm{R}$ & 6.60 & 5.39 & 4.90 & 2.85 \\
\hline & $\mathrm{L}$ & 6.90 & 5.90 & 4.81 & 3.07 \\
\hline \multirow[t]{2}{*}{ WP } & $\mathrm{R}$ & 6.56 & 5.08 & 4.82 & 2.79 \\
\hline & $\mathrm{L}$ & 6.81 & 5.74 & 4.94 & 2.87 \\
\hline \multirow[t]{2}{*}{ LAP M3 } & $\mathrm{R}$ & 11.97 & 9.55 & 8.79 & 5.16 \\
\hline & $\mathrm{L}$ & 11.29 & 9.48 & 9.08 & 5.25 \\
\hline \multirow[t]{2}{*}{ LLA } & $\mathrm{R}$ & 3.50 & 2.65 & 2.45 & 1.50 \\
\hline & $\mathrm{L}$ & 2.54 & 2.53 & 2.51 & 1.48 \\
\hline \multirow[t]{2}{*}{ LLP } & $\mathrm{R}$ & 7.81 & 6.73 & 6.06 & 2.99 \\
\hline & $\mathrm{L}$ & 7.19 & 6.68 & 6.27 & 2.82 \\
\hline \multirow[t]{2}{*}{ WAL } & $\mathrm{R}$ & 6.53 & 5.48 & 4.81 & 2.84 \\
\hline & $\mathrm{L}$ & 6.63 & 5.38 & 5.13 & 2.93 \\
\hline \multirow[t]{2}{*}{ WPL } & $\mathrm{R}$ & 6.95 & 5.82 & 4.97 & 2.76 \\
\hline & $\mathrm{L}$ & 6.73 & 6.04 & 4.93 & 2.90 \\
\hline
\end{tabular}

chapalmalense is approximately $30 \%$ longer than $P$. prisca (Table 1). Molarifoms: In P. prisca the P4 and M2 are longer than M1 and the posterior projection of M3 is posteriorly projected. Skull: In lateral view, the dorsal process of the premaxilla extends anteriorly to $\mathrm{P} 4$; the upper masseteric fossa (for the insertion of the pars profunda of the masseter muscle) and the temporal fossa is deeper in P. prisca. In the orbital portion, the alveolar protuberance of M3 extends posteriorly to the interorbital constriction; the lobes of M1/ $\mathrm{m} 1$ and $\mathrm{M} 2 / \mathrm{m} 2$ are asymmetrical. 
Table 4 Compared measurements (in $\mathrm{mm}$ ) of the lower molariforms of Dolichotis chapalmalense, D. improla, D. intermedia, D. major, D. patagonum, D. salinicola. Abbreviations L Left; lap anteroposterior length of molariforms; lla anteroposterior length of anterior lobe of molariforms; llp anteroposterior length of posterior lobe of molariforms; R right; wal mediolateral length of anterior lobe of molariforms; wpl mediolateral length of posterior lobe of molariforms; *estimative value

\begin{tabular}{|c|c|c|c|c|c|c|c|}
\hline & & $\begin{array}{l}\text { Dolichotis } \\
\text { chapalmalense }\end{array}$ & Dolichotis improla & Dolichotis intermedia & Dolichotis major & $\begin{array}{l}\text { Dolichotis } \\
\text { patagonum }\end{array}$ & $\begin{array}{l}\text { Dolichotis } \\
\text { salinicola }\end{array}$ \\
\hline & & MLP 15-229 & MACN-A 2176 & MACN-A 1256 & MACN-A 1482 & ave & \\
\hline \multirow[t]{2}{*}{ lap dental series } & $\mathrm{R}$ & 31.28 & 23.42 & - & $29.81 *$ & 26.15 & 16.25 \\
\hline & $\mathrm{L}$ & 30.19 & - & 24.42 & - & 27.89 & 16.49 \\
\hline \multirow[t]{2}{*}{ lap p4 } & $\mathrm{R}$ & 7.76 & 5.85 & - & - & 6.56 & 3.88 \\
\hline & $\mathrm{L}$ & 7.85 & - & 6.21 & - & 7.20 & 3.95 \\
\hline \multirow[t]{2}{*}{ lla } & $\mathrm{R}$ & 3.91 & 3.24 & & - & 3.81 & 2.06 \\
\hline & $\mathrm{L}$ & 4.11 & & 3.60 & - & 4.49 & 2.07 \\
\hline \multirow[t]{2}{*}{$11 \mathrm{p}$} & $\mathrm{R}$ & 3.51 & 2.70 & - & - & 2.50 & 1.69 \\
\hline & $\mathrm{L}$ & 3.11 & - & 2.38 & - & 2.62 & 1.68 \\
\hline \multirow[t]{2}{*}{ wal } & $\mathrm{R}$ & 5.29 & 3.83 & & - & 3.69 & 2.46 \\
\hline & $\mathrm{L}$ & 5.65 & - & 3.76 & - & 4.20 & 2.49 \\
\hline \multirow[t]{2}{*}{ wpl } & $\mathrm{R}$ & 5.89 & 4.53 & - & - & 4.66 & 2.94 \\
\hline & $\mathrm{L}$ & 5.21 & - & 4.75 & - & 5.08 & 3.07 \\
\hline \multirow[t]{2}{*}{ lap m1 } & $\mathrm{R}$ & 7.49 & 5.71 & - & - & 6.09 & 3.92 \\
\hline & $\mathrm{L}$ & 7.40 & - & 5.50 & - & 5.94 & 3.96 \\
\hline \multirow[t]{2}{*}{ lla } & $\mathrm{R}$ & 3.39 & 2.79 & - & - & 2.82 & 1.85 \\
\hline & $\mathrm{L}$ & 3.40 & - & 2.64 & - & 2.81 & 1.87 \\
\hline \multirow[t]{2}{*}{ llp } & $\mathrm{R}$ & 3.96 & 2.67 & - & - & 3.03 & 1.98 \\
\hline & $\mathrm{L}$ & 3.84 & - & 2.78 & - & 2.95 & 1.94 \\
\hline \multirow[t]{2}{*}{ wal } & $\mathrm{R}$ & 6.41 & 4.66 & - & - & 5.25 & 3.19 \\
\hline & $\mathrm{L}$ & 6.54 & - & 5.10 & - & 4.86 & 3.26 \\
\hline \multirow[t]{2}{*}{ wpl } & $\mathrm{R}$ & 6.61 & 5.17 & - & - & 5.31 & 3.17 \\
\hline & $\mathrm{L}$ & 6.04 & - & 5.25 & - & 4.94 & 3.22 \\
\hline \multirow[t]{2}{*}{ lap m2 } & $\mathrm{R}$ & 7.47 & 5.66 & - & 7.03 & 6.19 & 3.97 \\
\hline & $\mathrm{L}$ & 7.48 & - & 5.99 & - & 6,11 & 3.96 \\
\hline \multirow[t]{2}{*}{ lla } & $\mathrm{R}$ & 3.69 & 2.84 & - & 3.53 & 3.05 & 1.87 \\
\hline & $\mathrm{L}$ & 3.54 & - & 2.88 & - & 2.95 & 1.88 \\
\hline \multirow[t]{2}{*}{ llp } & $\mathrm{R}$ & 3.70 & 2.69 & - & 3.23 & 3.07 & 2.03 \\
\hline & $\mathrm{L}$ & 3.69 & - & 2.87 & - & 3.03 & 1.96 \\
\hline \multirow[t]{2}{*}{ wal } & $\mathrm{R}$ & 6.39 & 5.05 & - & 6.29 & 5.26 & 3.22 \\
\hline & $\mathrm{L}$ & 6.21 & - & 5.06 & - & 5.05 & 3.25 \\
\hline \multirow[t]{2}{*}{ wpl } & $\mathrm{R}$ & 6.00 & 5.09 & - & 6.41 & 5.26 & 3.17 \\
\hline & $\mathrm{L}$ & 6.12 & - & 5.25 & & 5.14 & 3.14 \\
\hline \multirow[t]{2}{*}{ lap m3 } & $\mathrm{R}$ & 8.74 & 6.03 & - & 7.71 & 7.05 & 4.32 \\
\hline & $\mathrm{L}$ & 8.17 & - & 6.73 & - & 7.32 & 4.49 \\
\hline \multirow[t]{2}{*}{ lla } & $\mathrm{R}$ & 3.70 & 2.87 & - & 3.52 & 3.08 & 1.89 \\
\hline & $\mathrm{L}$ & 3.77 & - & 2.93 & - & 3.19 & 1.93 \\
\hline \multirow[t]{2}{*}{ llp } & $\mathrm{R}$ & 4.72 & 3.26 & - & 4.23 & 3.70 & 2.30 \\
\hline & $\mathrm{L}$ & 4.09 & - & 3.73 & - & 3.91 & 2.41 \\
\hline \multirow[t]{2}{*}{ wal } & $\mathrm{R}$ & 5.82 & 4.91 & - & 5.97 & 5.15 & 2.98 \\
\hline & $\mathrm{L}$ & 5.10 & - & 5.22 & - & 5.24 & 3.03 \\
\hline \multirow[t]{2}{*}{ wpl } & $\mathrm{R}$ & 6.22 & 5.04 & - & 6.35 & 4.99 & 2.96 \\
\hline & $\mathrm{L}$ & 5.98 & - & 3.56 & - & 5.23 & 3.01 \\
\hline
\end{tabular}




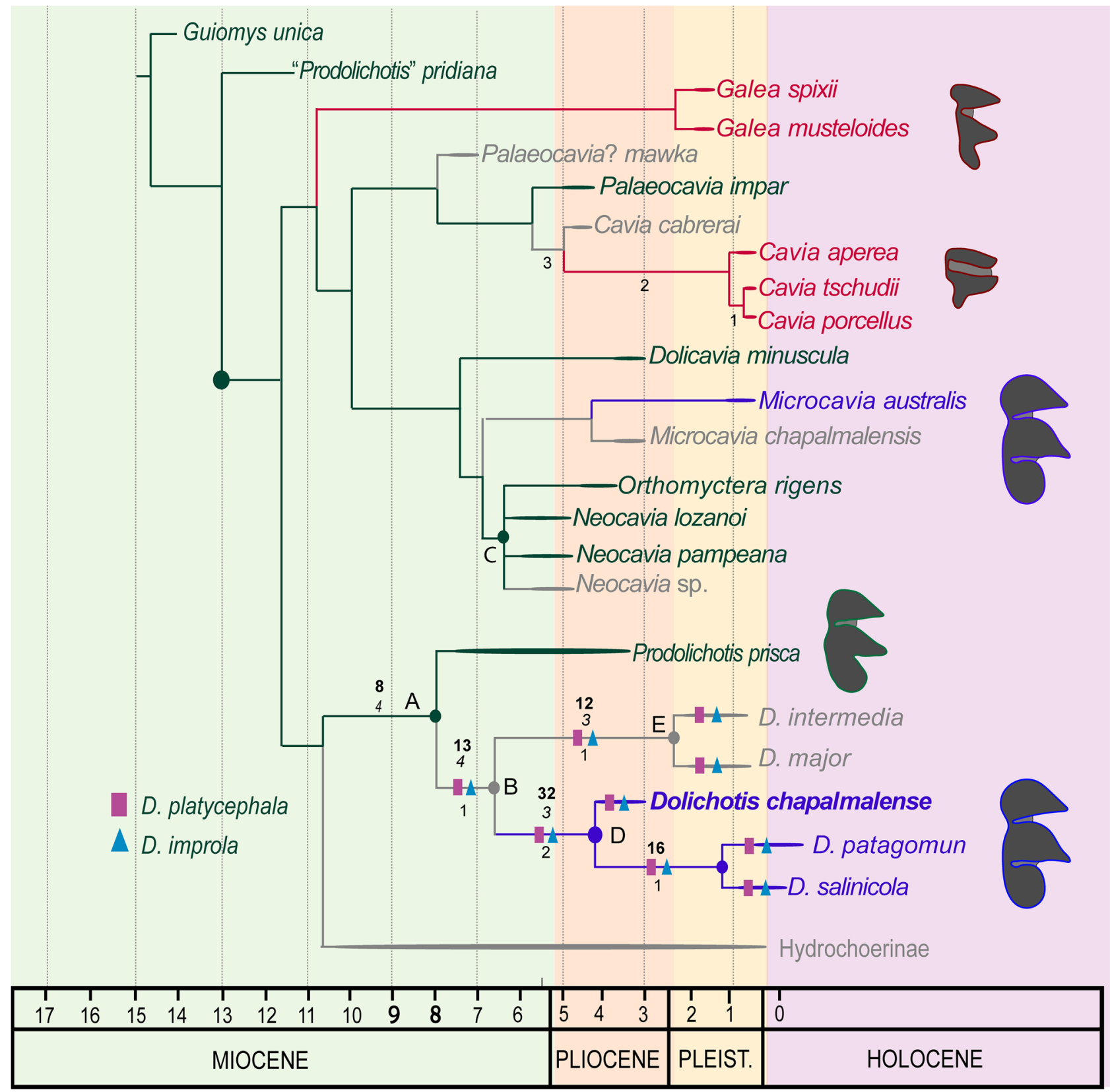

Fig. 7 Reduced strict consensus of 6,330 most parsimonious trees (MPTs) of 3,435 steps of phylogenetic analysis showing the Dolichotinae node. The phylogenetic tree is calibrated against geological time; periods are show in colors, Miocene, light green; Pliocene, orange; Pleistocene, yellow; Holocene pink. Upper case letters indicate nodes within Dolichotinae and Caviinae. Fuchsia rectangle and light blue

\section{Phylogeny and Similarity Analysis}

The cladistic analysis resulted in more than 6,330 most parsimonious trees (MPTs) of 3,435 steps. The reduced consensus of MPTs is shown in Fig. 7. The list of synapomorphies identified with the phylogenetic analysis is detailed in Supplementary Online Material 3. The analysis corroborates triangle show the multiple alternative positions in the most parsimonious trees of Dolichotis platycephala and D. improla (pruned from the consensus tree). The M3 drawings and color of branch indicate different states of the character 107. Numbers in bold indicate jackknife support values; numbers in italics represent resampling values; numbers below represent branch lengths

previous results in relation to the position of $D$. chapalmalense (e.g., Pérez 2010; Pérez and Pol 2012). This species is included within Dolichotinae (Fig. 7, node A), more related to the fossil and extant species of Dolichotis (node B) than to O. rigens (node C). Dolichotinae (node A) is supported by three unambiguous synapomorphies: nasolacrimal foramen laterally closed (character 48 , state 1); plane palatal 
surface (character 59, state 0 ); longitudinal furrow opposite to the hypoflexus on M1-M2 (character 142, state 0).

The fossil and extant species of Dolichotis form a clade (node B), which is supported by one unambiguous synapomorphy: symmetrical anterior and posterior lobes in M1/ $\mathrm{m} 1-\mathrm{M} 2 / \mathrm{m} 2$ (character 107, state 1 ). In the strict consensus, this node collapses in a polytomy generated by the instability of D. platycephala and D. improla, which take different positions in the MPTs. These taxa occupy alternative positions within the clade as sister group to each species or each node (Fig. 7). When these alternative positions of the unstable fossil taxa are ignored in the MPTs, the relationships within the clade are resolved. Dolichotis chapalmalense (node $\mathrm{D}$ ) is recovered as basal to the living forms $D$. patagomun and D. salinicola, whereas $D$. intermedia and $D$. major form a clade that is the sister group of the others (node E). Clade D is supported by two unambiguous synapomorphies: mandibular notch located above the occlusal surface of the dental series (character 14, state 0 ) and pterygoid shelf absent (character 18, state 2). Node $\mathrm{E}$ is supported by one unambiguous synapomorphy: horizontal crest extending up to the posterior margin of the mandibular condyle (character 31 , state 2).

The PCoA analysis showed clusters coinciding with the families Caviidae and Dasyproctidae and the three recognized subfamilies within Caviidae: Dolichotinae, Hydrochoerinae, and Caviinae (Fig. 8). The fossil forms of Caviidae were grouped within each subfamily, coinciding with the taxonomic and phylogenetic systematics proposed in works based on combined datasets (e.g., Pérez and Pol 2012; Madozzo-Jaén 2019). The scores of the first two coordinate axes represent between $55-75 \%$ of the variation of the data, depending on the taxon sampling considered (Fig. 8 and Supplementary Online Material 4). The first case includes only living Caviidae (Fig. 8a) in which the distance observed between $D$. patagonum and $D$. salinicola is intermediate between those present among the Caviinae genera (Microcavia, Cavia, Galea) and between the genera of Dasyproctidae (Dasyprocta and Myoprocta). Including the fossil species (Fig. 8b-c), the distance between D. patagonum and $D$. salinicola decreases dramatically by clustering with $D$. chapalmalense along each axis. This situation is maintained in all cases, whether or not the Dasyproctidae and Cuniculus families are included. The other species of Dolichotis ( $D$. intermedia and $D$. major) show a more variable length but clustering as Dolichotinae.

\section{Discussion}

\section{Considerations on Taxonomy}

Dolichotis chapalmalense is one of the species designated by Ameghino (1908) in his biostratigraphic study of the
Pliocene of the Atlantic coasts of Buenos Aires. The species was originally included in the genus Orthomyctera based on the only differential character of its size in relation to Dolichotis patagonum (Ameghino 1908). Later, some authors suggested the inclusion of this species in the genus Dolichotis (Kraglievich 1930a; Ubilla and Rinderknecht 2003; Madozzo-Jaén 2019), remarking that a more exhaustive taxonomic revision was necessary. On the other hand, Ameghino (1889) described at least four fossil species of Dolichotis (D. platycephala, D. intemedia, D. major, D. minor) for the Pleistocene and Holocene of Argentina, but none of them has been restudied since their original descriptions, and new materials have not been reported.

A detailed anatomical description of D. chapalmalense is provided here compared with: a) the extant species, b) the Pleistocene-Holocene taxa assigned to Dolichotis, and c) the type species of Orthomyctera and Prodolichotis. In addition, the most comprehensive phylogenetic analysis of Cavioidea is conducted here together with living and fossil forms and a combined dataset with morphological (cranial, dental, postcranial, tegumentary) and molecular (TTH, GHR, Cytochrome b,12S) characters. As a result, these analyses enabled a reinterpretation of the definition of Dolichotis.

Dolichotis chapalmalense shares several morphological characters with the extant species of this genus and differs in its larger size and some characteristics of the mandible and the cranium (see Emended Diagnosis and Description above). Moreover, it has differences with respect to $P$. prisca in cranial and dental characters. For example, one of the most striking ones is the asymmetry between the lobes (see character 107 in Suppl. Mat. 3) observed in P. prisca, Caviinae, Hydrochoerinae, and the extinct species of the stem group of Cavioidea sensu stricto (or "eocardiids"; see Pérez 2010). Otherwise, the species assigned here to Dolichotis (i.e., D. patagonum, $D$. salinicola, $D$. chapalmalense, $D$, intermedia, $D$. major, D. platycephala, and D. improla) share the symmetry of the lobes in the first and second molar. On the other hand, the differences with $O$. rigens are remarkable because this taxon is very close to Microcavia and Dolicavia (see above). Furthermore, the cladistic analysis yielded interesting results (Fig. 7). The inclusion of the PleistoceneHolocene species assigned to Dolichotis are recovered as a node collapsing in a polytomy (see Phylogeny and Similarity Analysis; Fig. 7). However, as it was explained before, this occurs because two of those species occupy unstable positions in this clade. This is probably because the holotype of $D$. improla consists of only the four lower cheek teeth without any remains of the dentary, resulting in several missing entries, and that of D. platycephala is a skull (needing further technical preparation) with intermediate characters that generate conflicts between them.

Recently, Campo et al. (2020) reviewed the current species of Dolichotinae at a molecular and morphometric level, 
Fig. 8 PCoA with Gower similarity of the morphological dataset (Supplementary Material 4). A 13 extant Cavioidea, the first two axes summarize $72 \%$ of the variation; B 49 extant and extinct Cavioidea, the first two axes summarize $50 \%$ of the variation; $\mathbf{C} 45$ extant and extinct Caviidae, the first two axes summarize $45 \%$ of the variation. Letters a-m represent extant species (unfilled symbols), numbers $\mathbf{0}-\mathbf{3 5}$ represent fossil species (filled symbols). a, Dolichotis patagonum; b, D. salinicola; c, Microcavia australis; $\mathbf{d}$, Cavia porcellus; e, C. avia tschudii; f, C. avia aperea; $\mathbf{g}$, Galea musteloides; $\mathbf{h}$, G. spixii; i, Kerodon rupestris; j, Hydrochoerus hydrochaeris; k, Cuniculus paca; l, Dasyprocta azarae $; \mathbf{m}$, Myoprocta acouchy; $\mathbf{0}$, Prodolichotis prisca; 1, D. chapalmalense; $\mathbf{2}$, D. platycephala; 3, D. major; $\mathbf{4}$, D. improla; $\mathbf{5}$, D. intermedia; $\mathbf{6}$, Orthomyctera rigens; 7 , Dolicavia minuscula; $\mathbf{8}$, Microcavia chapalmalensis; 9, Neocavia lozanoi; 10, N. pampeana; 11, Cavia cabrerai; $\mathbf{1 2}$, Palaeocavia impar; 13, Palaeocavia? mawka; 14, Cardiomys cavinus; 15, C. ardiomys leufuensis; 16, C. ameghinorum; 17, Caviodon multiplicatus; 18, C. aviodon australis; 19, C. andalhualensis; 20, C. cuyano; 21, C. pozzi; 22, Xenocardia diversidens; $\mathbf{2 3}$, Cardiatherium chasicoense; 24, C. ardiotherium paranense; $\mathbf{2 5}$, C. ardiotherium patagonicum; 26, C. calingastaense; $\mathbf{2 7}$, C. ardiotherium aff. C. orientalis; 28, Hydrochoeropsis dasseni; 29, H.? жауии; 30, Phugatherium novum; 31, $P$. cataclisticum; 32, P. saavedrai; 33, P. dichroplax; 34, Neochoerus; 35, Neoreomys australis. Convex hulls: Caviinae (green), Dolichotinae (blue), Hydrochoerinae (orange)
A

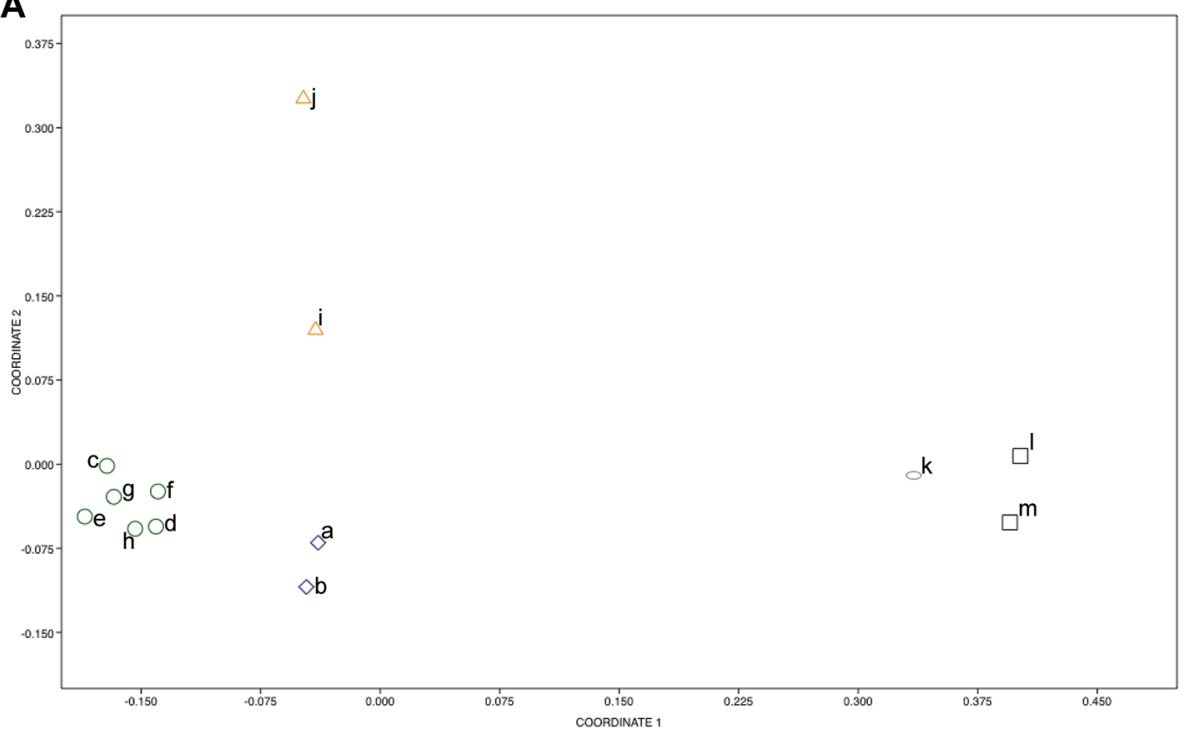

B

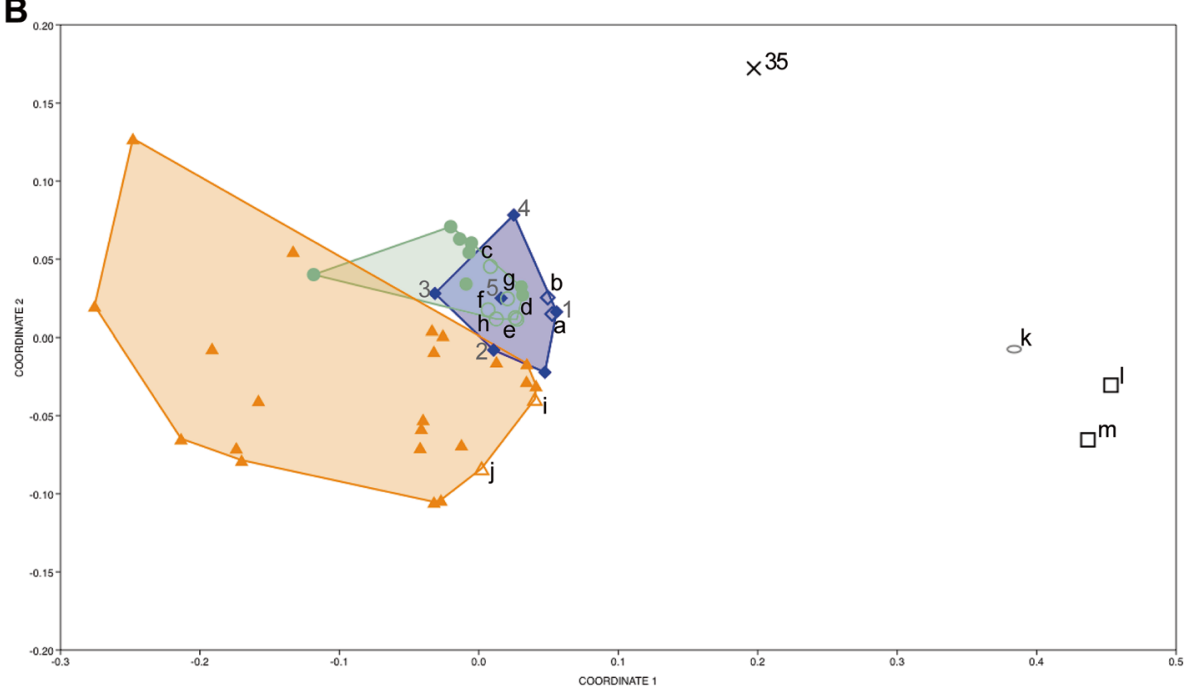

C

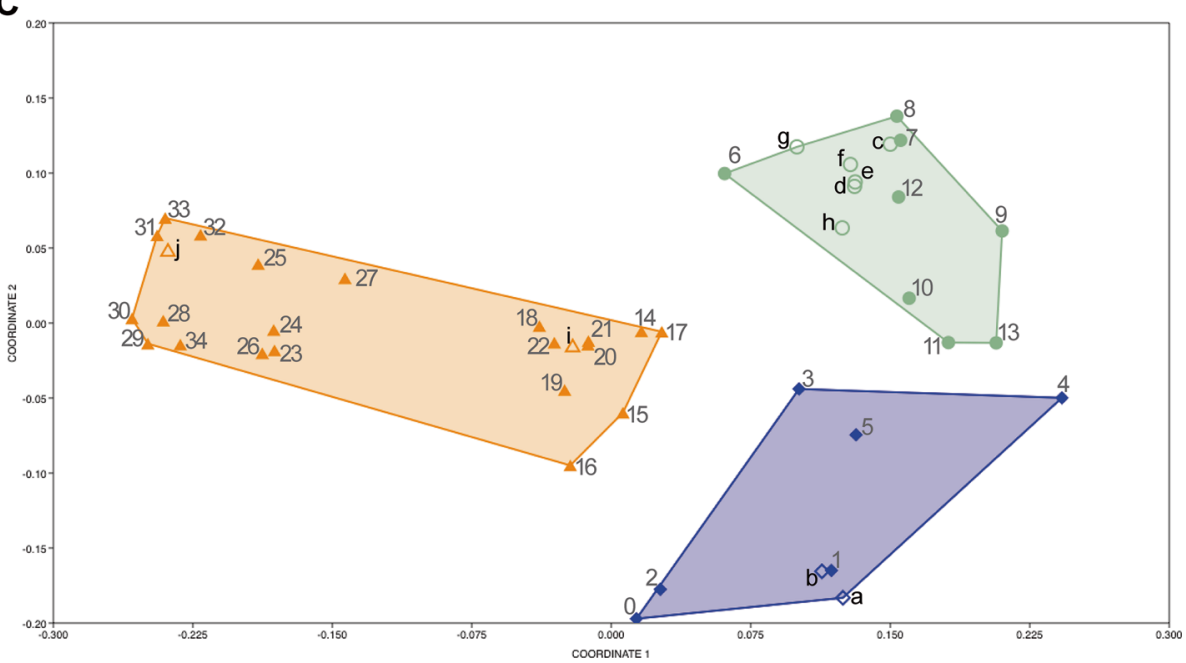


also taking into account some morphological characteristics, in order to establish an objective criterion in the decision of the generic assignment of related species in the context of Cavioidea (Patterson and Norris 2016). They concluded that the distinction between Dolichotis and Pediolagus is equal to or greater than differences seen for other intergeneric comparisons within Cavioidea. The work of Campo et al. (2020) is really valuable and the molecular distance between the two extant species of maras is unquestionable. However, their study has an almost exclusively neontological focus and overlooks the fossil record and the great morphological diversity at the osteological level (at least in the cranium, mandible, and teeth) undergone by Cavioidea during the last 30 million years (e.g., Kraglievich 1932; Kramarz 2006; Pérez 2010; Pérez and Pol 2012; Vucetich et al. 2015; Pérez et al. 2012, 2018; Madozzo-Jaén 2019). Discrete morphological characters, despite the predominance of molecular datasets, continue playing an important role in inferring phylogenetic trees, even as the sole source of evidence for most fossil taxa. For example, one of the simplest characters to see is the incisive foramina. Campo et al. (2020) explained the differences between $D$. patagonum and P. salinicola and concluded that one is proportionally shorter than the other (we agree and it is a difference that clearly separates these two species). However, when the incisive foramen is analyzed in the context of the Cavioidea, they are very similar to each other (in relation to shape and size), more than to any other group of the superfamily. This similarity leads us to consider both species belonging to the same genus.

Given the results of this work and that of Campo et al. (2020), different taxonomic decisions could be made. Following Campo and collaborators, if the extant species are considered as Dolichotis patagonum and Pediolagus salinicola it would be necessary to establish, at least, two new genera (one for $D$. chapalmalense and another for the node of $D$. major $+D$. intermedia), or in a more extreme case, one new genus for each species. Conversely, if the living species are considered as Dolichotis, the entire clade may be considered as Dolichotis. This particular decision is the most parsimonious and is based on the morphological similarities between this clade (even considering $D$. platycephala and D. improla) and the other Cavioidea (including the fossil record).

In this work, the living species and related fossil species are considered within a single genus, Dolichotis, based on the study of the alpha taxonomy of each taxon analyzing in detail anatomical characters of cavioids, mainly from osteology as it is the only comparable approach in the fossil record (at least in pre-Quaternary forms), establishing homology hypotheses. The number of changes expressed in branch length, within the lineage of Dolichotis, as a way to quantify the similarities and differences between genera, and between species of the same genus, was consistent with that of other genera in the context of Cavioidea (e.g., Cavia, Phugatherium; Fig. 7). Molecular data of living species were also taken into account, because they are crucial today in any evolutionary context.

The PCoA shows quite clearly (Fig. 8) the great similarity between $D$. salinicola, $D$. patagonum, and $D$. chapalmalense, which are clustering into Dolichotinae. Unstable taxa prevent us from making a tighter taxonomic decision; consequently, the most objective criterion in this context is to consider a single genus Dolichotis. Morpho-molecular cladistic analysis of maximum parsimony and the similarity analysis support the taxonomic decision, taking into account that a genus must be monophyletic. The incorporation of Quaternary maras shows that the history of Dolichotis is more complex than assumed. This comprehensive analysis shows a more complete scenario of the taxonomic and evolutionary history of Cavioidea in general, and the maras in particular.

\section{Divergence Times and Evolution of Characters}

Although in several phylogenetic analyses (e.g., Pérez 2010; Pérez and Pol 2012; Madozzo-Jaén 2019), D. chapalmalense has been recovered as a Dolichotinae, the taxonomic status and relationships of this species have not been evaluated in depth until this work. The evidence from an evolutionary perspective provided here supports the inclusion of the two species D. salinicola and D. patagonum in a single genus.

The Caviidae lineage dates back to the middle-late Miocene, and the earliest records of Dolichotinae thus far $(P$. prisca) are from the late Miocene (9-7 Ma). Three synapomorphies (see above) support this clade: 1) the presence of a longitudinal furrow opposite to the hypoflexid/us. This is the plesiomorphic state of the character and is shared with certain basal forms (e.g., Eocardia montana, Schistomys erro) and Guiomys unica (the sister group of Caviidae); 2) nasolacrimal foramen laterally closed; and 3) plane palatal surface. These characters are shared with Neoreomys; and the plane palatal surface is a characteristic present in some "cardiomyinae" (See Supplementary Material 3).

On the other hand, the ghost lineage of Dolichotis extends from 9 to $3.04 \mathrm{Ma}$, and then, in the Pliocene the divergence of the genus occurs. An important characteristic of Dolichotis (D. patagomun, D. salinicola, D. platycephala, and D. chapalmalense), with respect to the basal species of Dolichotinae (e.g., P. prisca) is: posterior projection of the M3 forming an incipient third lobe with cement in the flexus between the second and third lobes. This is a derived condition within Dolichotinae (Ubilla and Rinderknecht 2003). This character state arises independently at least twice in the family Caviidae in Dolichotis (Dolichotinae) and Microcavia (Caviinae) clades (both from the Pliocene), and probably a third time in the clade Hydrochoerinae (e.g., Procardiomys). 
However, it is interesting to note that in Miocene-Pliocene hydrochoerines, the M3 adds numerous posterior lobes/laminae (e.g., between four to more than 14; e.g., Vucetich et al. 2005; Deschamps et al. 2013; Pérez et al. 2018).

The study of fossil Dolichotinae from middle-late Miocene and early Pliocene sediments is necessary to complete the ghost lineage within this clade, in order to understand more thoroughly the sequences of acquisition of characters. The fossil record of Dolichotis is mainly concentrated in the middle latitude of South America. The analysis of other Pleistocene and Holocene stratigraphic sequences in areas that are part of or close to their current distribution will provide information of the distribution patterns of this species. The complete knowledge of their evolutionary history will certainly help to make important decisions about their conservation and that of the environment.

\section{The Pliocene, a Key Time in the History of Caviids}

The presence of $D$. chapalmalense in the Chapadmalal Formation (3.74-3.04 Ma) extends back the lineage of the genus at least one million years, to the middle Pliocene. This coincides with the age of the first fossil representatives of some living genera of Caviinae: Cavia cabrerai (4.74 Ma, Candela and Bonini 2018) and Microcavia chapalmalensis (<3.3 Ma; Ameghino 1908; Quintana 1996; Schultz et al. 1998; Prevosti et al. 2021). Since the end of the Miocene, the environmental conditions of the Pampean region were characterized by progressive aridization, comparatively colder climates, and more varied environmental fragmentation, an event known as "Edad de las Planicies Australes" ("Age of the Southern Plains"; Pascual and Bondesio 1982; Cione et al. 2015). In the northwest of Argentina (NWA), climatic deterioration with the expansion of relatively open savanna-like environments and increasingly arid conditions developed under climatic seasonality near the MiocenePliocene boundary, as a consequence of the elevation of western mountain ranges (Bossi et al. 2001; Bossi and Muruaga 2009; Bonini et al. 2017). Possibly, due to these environmental changes, new lineages with evolutionary novelties may have appeared in this period. The presence of a M3 with an additional strip of cement in $D$. chapalmalense and Microcavia chapalmalensis, as well as more complex cheek teeth of Cavia cabrerai (e.g., more lamination of the tooth, deeper flexid; Candela and Bonini 2018) could be related to the increase in consumption of abrasive particles due to coeval environmental changes (Latorre et al. 1997; Zachos et al. 2001; Ortiz-Jaureguizar and Cladera 2006; Bossi and Muruaga 2009; Hynek et al. 2012). The appearance of new lineages with some different dental characteristics (in the three subfamilies: Caviinae, Dolichotinae and Hydrochoerinae): suggests that the Pliocene was a key stage in the evolution of caviids, which resulted in the establishment of the living genera.

\section{Conclusions}

A new combination of Dolichotis chapalmalense is presented, together with a reinterpretation of the definition of Dolichotis, showing that its evolutionary history is more complex than so far assumed. Here we perform the most complete phylogenetic analysis of Caviidae (with living and fossil forms and a combined dataset with morphological (cranial, dental, postcranial, tegumentary) and molecular (TTH, GHR, Cytochrome b, 12S) characters.

From this analysis we conclude that Dolichotis chapalmalense is more closely related to Dolichotis than Orthomyctera rigens and clearly differentiated from the other fossil and current Dolichotis species (e.g., D. patagonum in tooth size; diastema length; $D$. salinicola in the coronoid process; $D$. intermedia in the extension of the horizontal crest; and D. major in the development of the masseteric crest). In addition, we support that the living maras belong to a single genus from the study of the alpha taxonomy, the osteological anatomy in Cavioidea, establishing homology hypotheses, as well as the morpho-molecular cladistic and similarity analyses.

The inclusion of $D$. chapalmalense enables the extension of the lineage of Dolichotis back to the Pliocene. The appearance of new lineages with some different dental characteristics suggests that the Pliocene was a key stage in the evolution of the Caviidae, which resulted in the establishment of the living genera.

Supplementary Information The online version contains supplementary material available at https://doi.org/10.1007/s10914-021-09559-4.

Acknowledgements The authors thank John Wible and Darin Croft, consecutive Editors-in-Chief of Journal of Mammalian Evolution, L. Kerber and an anonymous reviewer for their valuable comments on the revision of the manuscript, and the curators M. Reguero (Museo de La Plata, La Plata, Buenos Aires, [MLP], Argentina), A. Kramarz, S.M. Álvarez, L. Chornogubsky, P. Teta, and S. Lucero ("Museo Argentino de Ciencias Naturales Bernardino Rivadavia" [MACN], Argentina); M. Díaz, R. Barquez, and F. López Berrisbeistía ("Colección Mamíferos Lillo" [CML], Argentina), and † J.E. Powell, P.E. Ortiz, and R.F. González ("Colección Paleontología de Vertebrados Lillo" [PVL], Universidad Nacional de Tucumán [UNT], Argentina), for access to material under their care. This research was supported by PICT-20102613 and PICT-2016-0566 (MEP), G626 ("Consejo de Investigaciones de la Universidad Nacional de Tucumán”) and a Grant for Graduate Students of the "Asociación Paleontológica Argentina" 2015 (MCM-J).

Funding This study was financed by Agencia Nacional de Promoción Científica y Tecnológica (PICT-2010-2613 and PICT-2016-0566), Universidad Nacional de Tucumán (PIUNT G626), and Grant for Graduate Students of the "Asociación Paleontológica Argentina” 2015.

Availability of Data and Material See Materials and Methods 


\section{Declarations}

Conflicts of Interest/Competing Interests The authors declare that they have no conflict of interest.

\section{References}

Alonso Roldán V, Udrizar Sauthier DE, Giannoni SM, Campos CM (2019) Dolichotis patagonum. Categorización 2019 de los mamíferos de Argentina según su riesgo de extinción. Lista Roja de los mamíferos de Argentina. http://cma.sarem.org.ar

Álvarez A, Pérez SI, Verzi DH (2013) Ecological and phylogenetic dimensions of cranial shape diversification in South American caviomorph rodents (Rodentia: Hystricomorpha). Biol J Linnean Soc 110:98-913

Álvarez A, Vieytes EC, Becerra, F, Olivares AI, Echeverría AI, Verzi DH, Vassallo AI (2015) Diversity of craniomandibular morphology in caviomorph rodents: an overview of macroevolutionary and functional patterns. In: Vassallo AI, Antenucci CD (eds) The Biology of Caviomorph Rodents: Diversity and Evolution. SAREM, Mendoza, pp 199-228

Álvarez BB (1974) Los mamíferos fósiles del Cuaternario de Arroyo Toropí, Corrientes (Argentina). Ameghiniana 11:295-311

Ameghino F (1889) Contribución al conocimiento de los mamíferos fósiles de la República Argentina. Acta Acad Nac cienc Repúb Argent 6:1-1027

Ameghino F (1891) Caracteres diagnósticos de cincuenta especies nuevas de mamíferos fósiles argentinos. Rev Argent Hist Nat 1:129-167

Ameghino F (1908) Las formaciones sedimentarias de la región litoral de Mar del Plata y Chapadmalán. Mus Hist Nat Buenos Aires 3:343-428

Beilinson E, Gasparini GM, Tomassini RL, Zárate MA, Deschamps CM, Barendregt RW, Rabassa JO (2017) The Quequén Salado River Basin: geology and biochronostratigraphy of the MioPliocene boundary in the southern Pampean plain, Argentina. J S Am Earth Sci 76: 362-374

Bonini RA, Georgieff SM, Candela AM (2017) Stratigraphy, geochronology, and paleoenvironments of Miocene-Pliocene boundary of San Fernando, Belén (Catamarca, northwest of Argentina). J S Am Earth Sci 79:459-471

Bossi GE, Muruaga C (2009) Estratigrafía e inversión tectónica del rift Neógeno en el Campo del Arenal, Catamarca, NO Argentina. Andean Geol 36:311-340

Bossi G, Georgieff S, Gavriloff I, Ibáñez L, Muruaga C (2001) Cenozoic evolution of the intramontane Santa María basin, Pampean Ranges, northwestern Argentina. J S Am Earth Sci 14:725-734

Bowdich TE (1821) An Analysis of the Natural Classifications of Mammalia for the Use of Students and Travelers. Smith, Paris, $115 \mathrm{pp}$

Cabrera A (1953) Los roedores argentinos de la familia Caviidae. Publ Esc Vet 6:1-93

Caldas MM, Goodin D, Sherwood S, Campos Krauer JM, Wisely SM (2015) Land-cover change in the Paraguayan Chaco: 2000-2011. J Land Use Science 10:1-18

Campo DH, Caraballo DA, Cassini GH, Lucero SO, Teta P (2020) Integrative taxonomy of extant maras supports the recognition of the genera Pediolagus and Dolichotis within the Dolichotinae (Rodentia, Caviidae). J Mammal 101: 817-834

Campos CM, Tognelli MF, Ojeda, RA (2001) Dolichotis patagonum. Mammal Species 652:1-5

Candela AM, Bonini RA (2018) A new guinea pig (Rodentia, Caviomorpha) from northwestern Argentina: implications for the origin of the genus Cavia. J Vertebr Paleontol 37:e1352591
Candela AM, Pérez ME, Rasia L, Cerdeño ME (2021) New late Oligocene caviomorph rodents from Mendoza Province, central-western Argentina. J Vertebr Paleontol. https://doi.org/10.1080/02724634. 2021.1929264

Carreño LV, Pereyra H, Viglizzo EF (2009) Los servicios ecosistémicos en áreas de transformación agropecuaria intensiva. In: Morello J, Rodríguez A (eds) El Chaco sin bosques: La Pampa o el desierto del futuro. GEPAMA-UNESCO, Buenos Aires, pp 229-246

Cherem JJ, Ferigolo J (2012) Descrição do sincrânio de Cavia aperea (Rodentia, Caviidae) e comparação com as demais espécies do gênero no Brasil. Pap Avulsos zoöl 52:21-50

Cione AL, Gasparini GM, Soibelzon E, Soibelzon LH, Tonni EP (2015) The Great American Biotic Interchange: A South American Perspective. Springer, Netherlands

Cione AL, Tonni EP (1999) Biostratigraphy and chronological scale of uppermost Cenozoic in the Pampean area, Argentina. Quat $S$ Am Antarct Penins 12:23-51

Cione AL, Tonni EP (2001) Correlation of Pliocene to Holocene southern South American and European vertebrate-bearing units. Boll Soc Paleontol Ital 40:167-173

Cione AL, Tonni EP (2005) Bioestratigrafía basada en mamíferos del Cenozoico superior de la provincia de Buenos Aires, Argentina. Geol recur miner prov Buenos Aires 11:183-200

del Papa LMD, De Santis, LJM, Togo J (2010) Consumo de roedores en el sitio Villa la Punta: agro-alfarero temprano de la región Chaco-Santiagueña. Intersec Antropol 11:29-40

Deschamps CM, Vucetich MG, Montalvo CI, Zárate MA (2013) Capybaras (Rodentia, Hydrochoeridae, Hydrochoerinae) and their bearing in the calibration of the late Miocene-Pliocene sequences of South America. J S Am Earth Sci 48:145-158

Dunnum JL (2015) Family Caviidae. In: Patton JL, Pardiñas UFJ, D` Elía G (eds) Mammals of South America: Volume 2 Rodents. University of Chicago Press, Chicago, pp 690-726

Fischer De Waldheim G (1817) Adversaria zoologica. Memoires de la Societe Imperiale des Naturalistes de Moscou 5:357-428

Francia A, Zurita AE, Orfeo O, Miño-Boilini AR, Erra G, Zacarías S, Rodríguez-Bualó M, Alcaraz MA, Lutz AI (2019) Paleontología y geología del Pleistoceno de la provincia de Corrientes, Argentina. Acta geol Lilloana 26:165-192

Gervais H, Ameghino F (1880) Los mamíferos fósiles de la América del Sur. Sabih e Igon

Goloboff PA, Catalano SA (2016) TNT version 1.5, including a full implementation of phylogenetic morphometrics. Cladistics 32:221-238

Hammer Ø, Harper DAT, Ryan PD (2001) PAST: Paleontological Statistics Software Package for Education and Data Analysis. Palaeontol Electron 4:1-9

Herbst R, Álvarez BB (1977) Nota sobre dos formaciones del Cuaternario de Corrientes, República Argentina. FACENA Rev de la Facultad de Ciencias Exactas y Naturales y Agrimensura 1:7-17

Hynek SA, Passey BH, Prado JL, Brown FH, Cerling TE, Quade J (2012) Small mammal carbon isotope ecology across the Miocene-Pliocene boundary, northwestern Argentina. Earth Planet Sci Lett 321-322:177-188

Kerber L, Lopes RP, Vucetich MG, Ribeiro AM, Pereira JC (2011) Chinchillidae and Dolichotinae rodents (Rodentia, Hystricognathi, Caviomorpha) from the late Pleistocene of southern Brazil. Rev Bras Paleontol 14:229-238

Kraglievich L (1930a) Diagnosis osteológico-dentaria de los géneros vivientes de la subfamilia Caviinae. Anales Mus Nac Hist Nat Buenos Aires 36:59-95

Kraglievich L (1930b) La formación friaseana del río Frías, río Fenix, laguna Blanca, etc. y su fauna de mamíferos. Physis 10: 127-161

Kraglievich L (1932) Diagnosis de nuevos géneros y especies de roedores cávidos y eumegámidos fósiles de la Argentina. Imprenta y Casa Editora, Buenos Aires 
Kramarz A (2006) Neoreomys and Scleromys (Rodentia, Hystricognathi) from the Pinturas Formation, late early Miocene of Patagonia, Argentina. Rev Mus Argent Cienc Nat 8:53-62

Latorre C, Quade J, Mcintosh WC (1997) The expansion of the C4 gases and global changes in the late Miocene: stable isotope evidence from the Americas. Earth Planet Sci Lett 146:83-96

Lema V, Giovannetti M, Deschamps C, Capparelli A, Raffino R (2009) Análisis de restos faunísticos en el sitio inkaico El Shincal (Catamarca, Argentina). Comparación con información arqueobotánica y análisis cerámico. In: Capparelli A, Chevalier A, Piqué R (eds) La Alimentación en América Precolombina, una aproximación interdisciplinaria. Consejo Superior de Investigaciones Científicas, Madrid, pp 97-112

Madozzo-Jaén MC (2019) Systematic and phylogeny of Prodolichotis prisca (Caviidae, Dolichotinae) from the northwest of Argentina (late Miocene-early Pliocene): advances in the knowledge of the evolutionary history of maras. CR Palevol 18:33-50

Marelli CA (1927) Notas anatómicas que fundamentan el género Pediolagus de roedores hystricomorfos. Mem Jardín Zool La Plata Argentina 3:1-11

Mares MA, Ojeda RA (1982) Patterns of diversity and adaptation in South American hystricognath rodents. In: Mares MA, Genoways $\mathrm{HH}$ (eds) Mammalian Biology in South America. Pymatuning Laboratory of Ecology, Linesville, pp 393-432

Martínez Sarrat C (2009) Nueva localidad fosilífera del Pleistoceno de la provincia de Córdoba, Argentina: implicancias bioestratigráficas. Ameghiniana 46:37R

Mones A (1991) Monografía de la familia Hydrochoeridae (Mammalia: Rodentia). Cour Forsch Senckenberg 134:1-235

Mora MS, Ojeda AA (2019) Dolichotis salinicola. Categorización 2019 de los mamíferos de Argentina según su riesgo de extinción. Lista Roja de los mamíferos de Argentina. http://cma.sarem.org.ar

Ortiz-Jaureguizar E, Cladera GA (2006) Paleoenvironmental evolution of southern South America during the Cenozoic. J Arid Environ $66: 498-532$

Pascual R, Bondesio P (1982) Un roedor Cardiatheriinae (Hydrochoeriidae) de la Edad Huayqueriense (Mioceno tardío) de La Pampa. Sumario de los ambientes terrestres en la Argentina durante el Mioceno. Ameghiniana 19:19-35

Patterson BD, Norris RW (2016) Towards a uniform nomenclature for ground squirrels: the status of the Holarctic chipmunks. Mammalia 80:241-251

Pérez ME (2010) A new rodent (Cavioidea, Hystricognathi) from the middle Miocene of Patagonia, mandibular homologies, and the origin of the crown group Cavioidea sensu stricto. J Vertebr Paleontol 30:1848-1859

Pérez ME, Deschamps CM, Vucetich MG (2018) Diversity, phylogeny and biogeography of the South American "Cardiomyine" rodents (Hystricognathi, Cavioidea) with a description of two new species. Pap Palaeontol 4:1-19

Pérez ME, Krause M, Vucetich MG (2012) A new species of Chubutomys (Rodentia, Hystricognathi) from the late Oligocene of Patagonia and its implications on the early evolutionary history of Cavioidea sensu stricto. Geobios 45:573-580

Pérez ME, Pol D (2012) Major radiations in the evolution of caviid rodents: reconciling fossils, ghost lineages, and relaxed molecular clocks. PLoS One 7:1-21

Pocock RI (1922) On the external characters of some hystrichomorph rodents. Proc Zool Soc London 1992: 365-427

Prevosti FJ, Romano CO, Forasiepi AM, Hemming S, Bonini R, Candela AM, Cerdeño E, Madozzo-Jaén MC, Ortiz PE, Pujos F, Rasia L, Schmidt GI, Taglioretti M, MacPhee RDE, Pardiñas UF (2021) New radiometric $40 \mathrm{Ar}-39 \mathrm{Ar}$ dates and faunistic analyses refine evolutionary dynamics of Neogene vertebrate assemblages in southern South America. Sci Rep 11:1-14
Quintana C (1996) Diversidad del roedor Microcavia (Caviomorpha, Caviidae) de América del Sur. Mastozool Neotrop 3:63-86

Quintana C (1997) El roedor Dolicavia minuscula (Caviomorpha, Caviidae) del Plioceno superior de la provincia de Buenos Aires, Argentina. His Anim 3:55-71

Rodriguez Larredo C (1998) Estudio arqueozoológico del sitio Inca Potrero-Chaquiago, Barrios La Solana y Retambay, Andalgalá, Pcia de Catamarca (Argentina). Relac Soc Argent Antropol 22:203-245

Rovereto C (1914) Los estratos araucanos y sus fósiles. Imprenta Alsina, Buenos Aires

Rowe DL, Honeycutt RL (2002) Phylogenetic relationships, ecological correlates, and molecular evolution within the Cavioidea (Mammalia, Rodentia). Mol Biol Evol 19:263-277

Schultz PH, Zárate M, Hames W, Camilión C, King J (1998) A 3.3Ma impact in Argentina and possible consequences. Science 282: 2061-2063

Tonni EP (1981) Pediolagus salinicola (Rodentia, Caviidae) en el Pleistoceno tardío de la provincia de Buenos Aires. Ameghiniana 18:123-126

Tullberg T (1899) Ueber das System der Nagethiere, eine phylogenetische Studie. Nova Acta Regiae Soc Sci Ups 18:1-514

Ubilla M, Perea D, Aguilar CG, Lorenzo N (2004) Late Pleistocene vertebrates from northern Uruguay: tools for biostratigraphic, climatic and environmental reconstruction. Quat Int 114:129-142

Ubilla M, Perea D, Rinderknecht A, Corona A (2009) Pleistocene mammals from Uruguay: biostratigraphic, biogeographic and environmental connotations. Quat do Rio Grande do Sul 217-230

Ubilla M, Rinderknecht A (2003) A late Miocene Dolichotinae (Mammalia, Rodentia, Caviidae) from Uruguay, with comments about the relationships of some related fossil species. Mastozool Neotrop 10:293-302

Verzi DH, Quintana CA (2005) The caviomorph rodents from the San Andrés Formation, east-central Argentina, and global late Pliocene climatic change. Palaeogeogr Palaeoclimatol Palaeoecol 219:303-320

Vezzosi RI (2015) Diversidad de los mamíferos del Pleistoceno de la Provincia de Santa Fe, Argentina: aspectos taxonómicos, bioestratigráficos y paleobiogeográficos relacionados. $\mathrm{PhD}$ thesis. Universidad Nacional de La Plata

Vucetich MG, Arnal M, Deschamps CM, Pérez ME, Vieytes CE (2015) A brief history of caviomorph rodents as told by the fossil record. In: Vassallo AI, Antenucci CD (eds) The Biology of Caviomorph Rodents: Diversity and Evolution. SAREM, Mendoza, pp 11-62

Vucetich MG, Deschamps CM, Olivares AI, Dozo MT (2005) Capybaras, size, shape, and time: a model kit. Acta Palaeontol Pol 50:259-272

Wahlert JH (1974) The cranial foramina of protrogomorphous rodents: an anatomical and phylogenetic study. Bul Mus Comp Zool $146: 363-410$

Waterhouse GE (1839) Observations on the Rodentia, with a view to point out the groups, as indicated by the structure of the crania in this order of Mammals. Magazine of Natural History 3:90-96, 593-600

Wible JR, Wang Y, Li C, Dawson MR (2005) Cranial anatomy and relationships of a new ctenodactyloid (Mammalia, Rodentia) from the early Eocene of Hubei Province, China. Ann Carnegie Mus 74:91-151

Woods CA, Howland EB (1979) Adaptive radiation of capromyid rodents: anatomy of the masticatory apparatus. J Mammal 60:95-116

Woods CA, Kilpatrick CW (2005) Infraorder Hystricognathi. In: Wilson DE, Reeder DM (eds) Mammal Species of the World: A Taxonomic and Geographic Reference, third ed. Johns Hopkins University Press, Baltimore, pp 1538-1600

Zachos J, Pagani M, Sloan L, Thomas E, Billups K (2001) Trends, rhythms, and aberrations in global climate $65 \mathrm{Ma}$ to present. Science 292:686-693 